\title{
WATER RESOURCES ACTIVITIES \\ IN KENTUCKY, 1993-94
}

Compiled by Linda S. Maglothin and Robert W. Forbes

U.S. GEOLOGICAL SURVEY

Open-File Report 93-157

Louisville, Kentucky

1994 


\section{U.S. DEPARTMENT OF THE INTERIOR \\ BRUCE BABBITT, Secretary}

U.S. GEOLOGICAL SURVEY

ROBERT M. HIRSCH, Acting Director

For additional information write to:

\section{District Chief}

U.S. Geological Survey

2301 Bradley Avenue

Louisville, KY 40217
Copies of this report can be purchased from:

U.S. Geological Survey

Earth Science Information Center

Open-File Reports Section

Box 25286, MS 517

Denver Federal Center

Denver, CO 80225 


\section{A MESSAGE FROM THE DISTRICT CHIEF}

In recent years we have become increasingly aware of problems related to protection of the environment. The solution to these problems is not and cannot be the responsibility of any one agency or individual alone. Citizens, industries, and governmental agencies must recognize their roles and responsibilities in maintaining our State and Nation in a manner that will enable us to live happy, healthy, and prosperous lives.

The task before us is not an easy one. Our Nation achieved greatness on the basis of its pioneer spirit, vast natural resources, and industrial genius. To continue as a great nation, we must develop and manage our resources wisely, and at the same time, protect the quality of the environment in which we live. The Kentucky District of the U.S. Geological Survey, Water Resources Division, recognizes its responsibility in this endeavor.

The Kentucky District, in cooperation with State, local, and other Federal agencies, has been collecting hydrologic data in Kentucky since the early 1900's and conducting water-resources studies since the mid-1900's to ensure that facts are available to aid in the development, management, protection, and conservation of our water resources. The scope of the present cooperative program is broad; it includes elements ranging from basic data collection on the occurrence, availability, and quality of water to detailed research studies in areas such as urban hydrology, fate and transport of toxic substances, karst hydrology, bridge scour, and aquatic biology.

The water-resources program of the Kentucky District is described in this publication. The effort devoted to basic and applied research, data collection, and interpretive studies, which will provide the facts to guide wise management of the water resources and protection of the environment, is evidence that we have accepted the challenge to do our part to meet the present and future needs of our State and Nation. Our goal is to continue to explore every opportunity to promote communication, education, and cooperation by working together across lines of scientific disciplines and across lines of governmental responsibility to achieve the level of excellence needed to provide earth science for the common good now and for future generations.

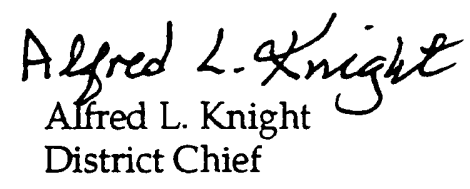





\section{CONTENTS}

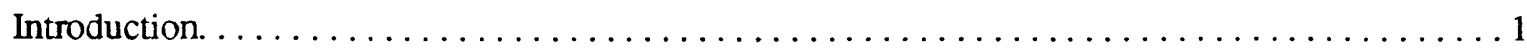

Origin and mission of the U.S. Geological Survey $\ldots \ldots \ldots \ldots \ldots \ldots \ldots \ldots \ldots \ldots \ldots$

Kentucky District organization. . . . . . . . . . . . . . . . . . . . . . . . 3

U.S. Geological Survey, Water Resources Division, offices in Kentucky. . . . . . . . . . 4

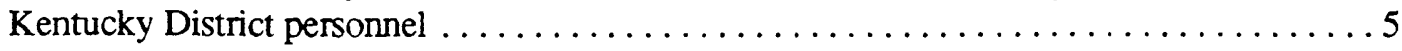

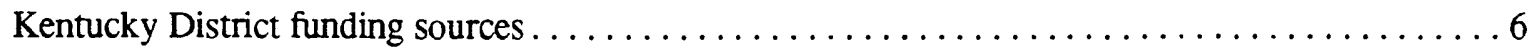

Kentucky District public-information and public-service activities. . $\ldots \ldots \ldots \ldots \ldots \ldots \ldots$

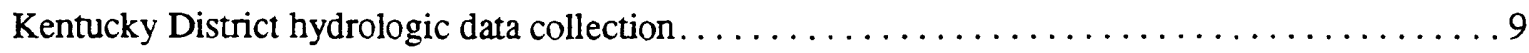

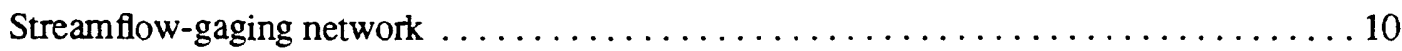

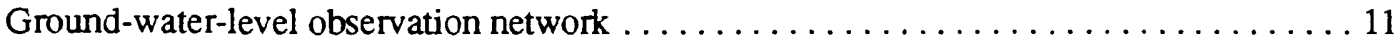

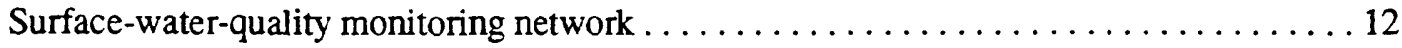

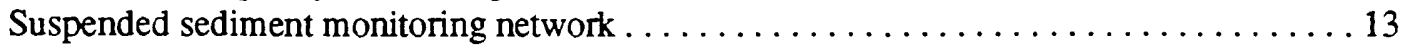

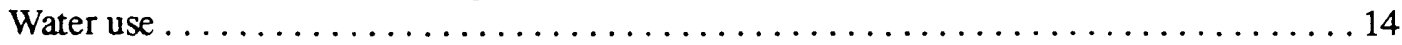

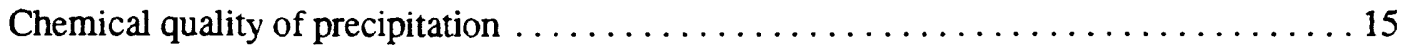

Kentucky District hydrologic investigations $\ldots \ldots \ldots \ldots \ldots \ldots \ldots \ldots \ldots \ldots \ldots \ldots \ldots \ldots \ldots \ldots \ldots$

National Water-Quality Assessment program--Kentucky River basin . . . . . . . . 18

Regionalization of low-flow characteristics of Kentucky streams . . . . . . . . . . . . 19

Geographic information system data base for hydrologic research $\ldots \ldots \ldots \ldots \ldots \ldots 20$

Hydrologic assessments at leaking underground storage tank sites $\ldots \ldots \ldots \ldots \ldots \ldots 21$

Urban hydrology and surface-water quality of Jefferson County $\ldots \ldots \ldots \ldots \ldots \ldots 22$

Hydrologic investigation of stress-relief fractures of a

steep-sloped valley in the coal areas of eastern Kentucky . . . . . . . . . . . 23

Geohydrologic mapping of the recharge areas of municipal

water-supply springs in a karst terrane near Elizabethtown . . . . . . . . . . 24

Pilot project to update the Kentucky hydrologic investigations atlases $\ldots \ldots \ldots \ldots \ldots 25$

Fate and transport of agricultural chemicals . . . . . . . . . . . . . . . . . . 26

Determination and regionalization of harmonic-mean flows for streams . . . . . . . 27

Assessment of the effectiveness of best management

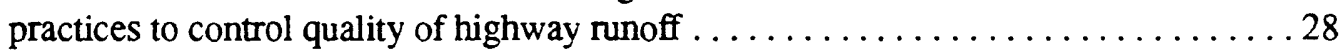

Investigation of potential environmental contamination at the Kentucky Air National Guard facility, Standiford Field. . . . . . . . . . . . . . 29

Simulation of ground-water flow and the behavior of contaminant plumes in the alluvial aquifer, Calvert City ................ 30

Empirical methods for determining boundary

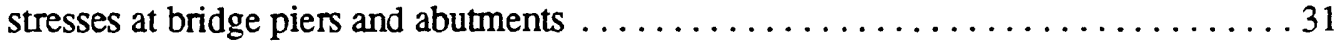

Simulation of ground-water flow, Ohio River alluvial aquifer, Owensboro . . . . . . . 32

Freshwater mussels--Relevance of shell-layer and tissue accumulation processes for describing water-quality trends. . . . . . . . . . . . . . . . 33

Investigation of subsurface flow and karst hydrology of the Lost River watershed, south-central Indiana. . . . . . . . . . . . . . . . 34

Determination of the catchment area and hydrologic characteristics of Boiling Spring, Fort Campbell military base, Kentucky-Tennessee. . . . . . . . . 35

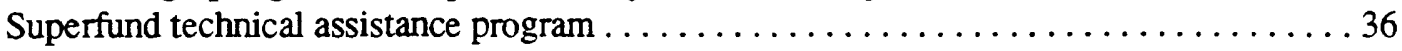


CONTENTS--continued

Page

Sources of water-resources information and references for Kentucky. . . . . . . . . . . 37

Professional papers . . . . . . . . . . . . . . . . . . . . . . . . . 39

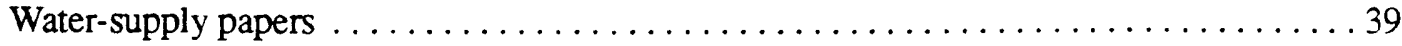

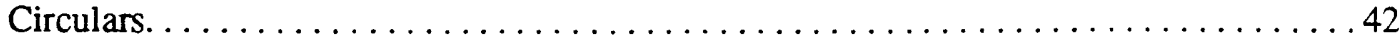

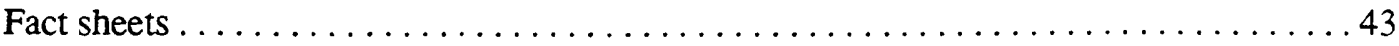

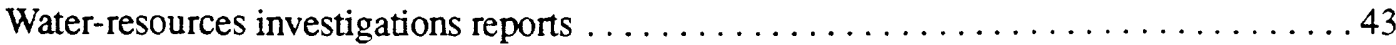

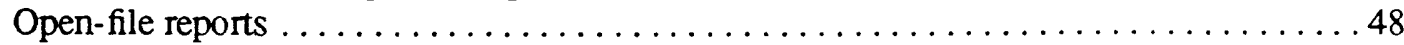

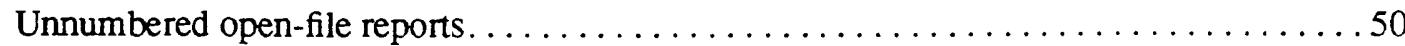

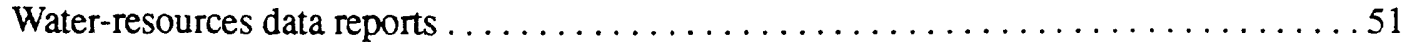

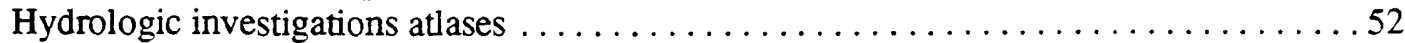

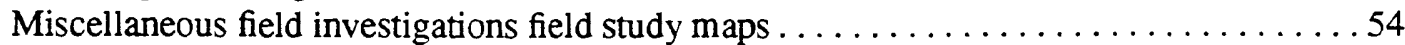

Publications of the Kentucky Geological Survey prepared

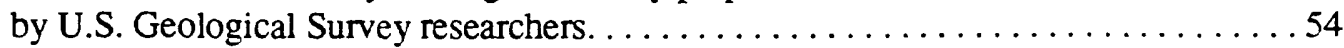

Other publications of the U.S. Geological Survey researchers for Kentucky . . . . . . . 56 


\title{
WATER RESOURCES ACTIVITIES IN KENTUCKY, 1993-94
}

\author{
Compiled by Linda S. Maglothin and Robert W. Forbes
}

\section{INTRODUCTION}

The U.S. Geological Survey (USGS) is the principal Federal water-resources data collection and investigation agency. Through the Water Resources Division District Office in Kentucky, the USGS investigates the occurrence, distribution, quantity, movement, and chemical and biological quality of surface and ground water in the State. The mission of this program is to collect, interpret. and publish information on water resources. Almost all research and data collection is a cooperative effort in which planning and financial support are shared by State and local agencies and governments. Other activities are funded by other Federal agencies or by direct Congressional appropriation.

This report is intended to inform the public and cooperating agencies, vitally interested in the water resources of Kentucky, as to the current status of the District's data collection and investigation program. Included in the report are summaries of water-resources activities in Kentucky conducted by the USGS. Also included is a description of the USGS mission and program, District organization. funding sources and cooperating agencies, and a list of USGS publications relevant to the water resources of the State.

\section{ORIGIN AND MISSION OF THE U.S. GEOLOGICAL SLRVEY}

The USGS was established by an act of Congress on March 3, 1879, to provide a permanent Federal agency to conduct the systematic and scientific classification of the public lands, and examination of the geological structure, mineral resources, and products of national domain. An integral part of that original mission includes publishing and disseminating the earth-science information needed to understand, effectively utilize, and manage the Nation's energy, land, mineral, and water resources.

A major effort of fulfilling the mission of the USGS is provided by the Water Resources Division. The Water Resources Division provides the hydrologic information and understanding needed for the optimum utilization, management, and protection of the Nation's water resources for the overall benefit of the people of the United States.

Since 1879, the research and fact-finding role of the USGS has grown and been modified to meet the changing needs of the Nation it serves. As part of that evolution, the USGS has become the Federal Government's largest earth-science research agency, the largest civilian map-making agency, the primary source of data for surface-water and ground-water resources, and the employer of the largest number of professional earth scientists. Today's programs serve a diversity of the Nation's needs and users.

Along with its continuing commitment to meet the growing and changing earth-science needs of the Nation, the USGS remains dedicated to its original mission to collect, analyze, interpret, publish, and disseminate information about the natural resources of the Nation--providing Earth Science in the Public Service. 
This is accomplished, in large part, through District offices in cooperation with other Federal, State, and local agencies by:

- Collecting, on a systematic basis, data needed for the continuing determination and evaluation of the quantity, quality, and use of the Nation's water resources.

- Conducting analytical and interpretive water-resources appraisals describing the occurrence, availability, and the physical, chemical, and biological characteristics of surface water and ground water.

- Conducting supportive basic and problem-oriented research in hydraulics, hydrology, water chemistry and biology, and related fields of science to improve the scientific basis for investigations and measurement techniques and to understand hydrologic systems sufficiently well to quantitatively predict their response to stress, either natural or human-induced.

- Disseminating water data and the results of these investigations and research through reports, maps, computerized information services, and other forms of public releases.

- Coordinating the activities of Federal agencies in the acquisition of water data for streams, lakes, reservoirs, estuaries, and ground water.

- Providing scientific and technical assistance in hydrologic fields to other Federal, State, and local agencies, to licensees of the Federal Energy Regulatory Commission, and to international agencies on behalf of the U.S. Department of State.

- Acquiring, developing, and disseminating information on water-related natural hazards such as droughts, floods, land subsidence, landslides, mudflows, and volcanoes.

- Administering the provisions of the Water Resources Research Act of 1984, which include the State Water Resources Research Institutes and the Research Grants and Contracts Programs.

- Supporting the provisions of the National Environmental Policy Act of 1969 and managing USGS participation in natural resources surveys in response to the Comprehensive Environmental Response, Compensation, and Liability Act (CERCLA or Superfund) of 1980, as amended by the Superfund Amendments and Reauthorization Act of 1986 (SARA).

The Kentucky District and agencies of the State of Kentucky have had cooperative agreements for the systematic collection of streamflow data since 1938. However, the collection of surface-water data was begun at a few selected sites in 1907. The earliest recorded ground-water levels in Kentucky were measured in 1935 in the Louisville-Jefferson County area under the supervision of the Louisville City Engineer. These records were made available to the USGS in the early 1940's when ground-water resources investigations were started in the area. Also in the 1940's, the beginnings of a statewide ground-water level observation network was implemented; however, State cooperator support for statewide ground-water data collection was discontinued in 1984. Over the past several decades, numerous investigative reports have been completed. A listing of reports published by the USGS, or by the cooperating agency for a specific project, relevant to the water resources of Kentucky is provided later in this report. 


\section{KENTUCKY DISTRICT ORGANIZATION}

The Kentucky District is part of the Great Lakes-Ohio Valley Area of the USGS Water Resources

Division which includes mlinois, Indiana, Michigan, Ohio, and Wisconsin. The District is comprised of the State of Kentucky with the District office in Louisville and field headquarters in Paducah, Prestonsburg, and Williamsburg. The organization of the District is shown below, the location of USGS offices in Kentucky is shown on page 4, and the list of District personnel (many of whom assisted in gathering information for this report) is given on page 5 .

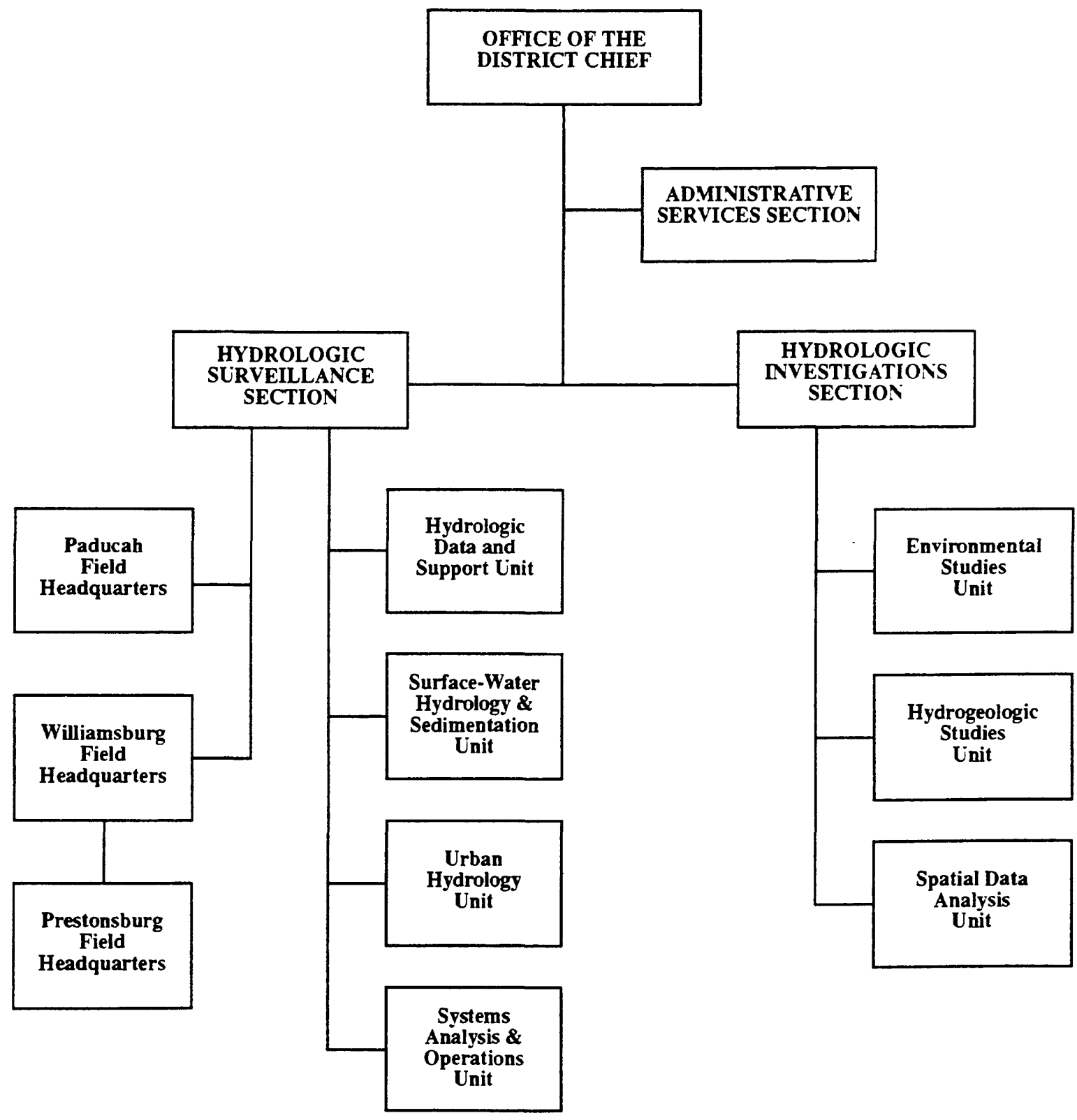




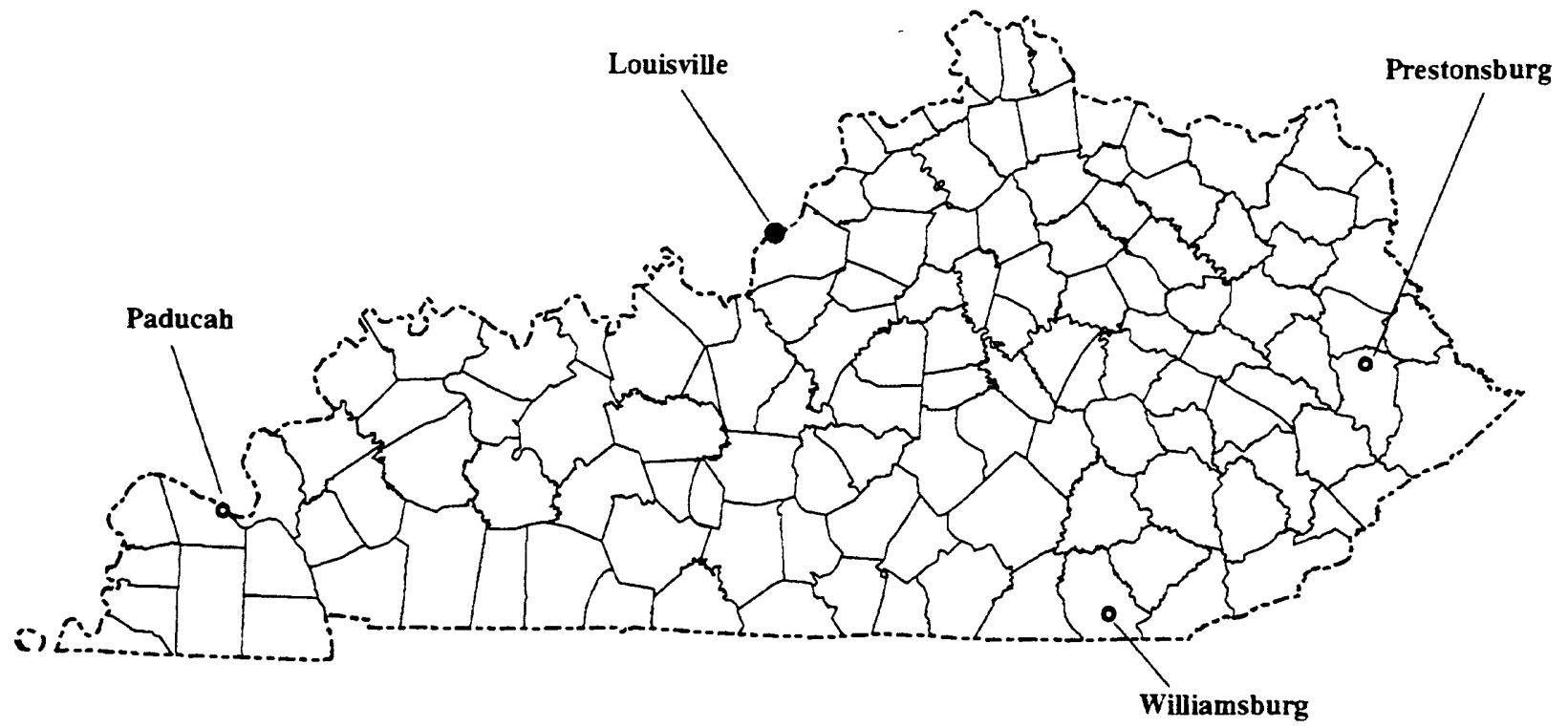

U.S. GEOLOGICAL SURVEY, WATER RESOURCES DIVISION, OFFICES IN KENTUCKY

District Office

2301 Bradley Avenue

Louisville, KY 40217

Telephone: (502) 582-5242

Paducah Field Headquarters

501 Broadway, Room M17

Paducah, KY 42001

Telephone: (502) 443-1252

Prestonsburg Field Headquarters

HCR 70, Box 541

Van Lear, KY 41265

Telephone: (606) 886-9432

Williamsburg Field Headquarters

P. O. Box 1028

Williamsburg, KY 40769

Telephone: (606) 549-2406 


\section{KENTUCKY DISTRICT PERSONNEL}

\section{OFFICE OF THE DISTRICT CHIEF}

Knight, Alfred L., District Chief

Maglothin, Linda S.

\section{ADMINISTRATIVE SERVICES}

\section{SECTION}

Haynes, C. Regina,

Administrative Officer

Vertrees, Linda $\mathrm{K}$.

Wolfe, Edith M.

\section{HYDROLOGIC INVESTIGATIONS}

\section{SECTION}

Mesko, Thomas O., Assistant District Chief

Forbes, Robert W.

Haag, Kim H.

Jarrett, G. Lynn

Mueller, David S.

Mull, Donald S.

Nelson, Hugh L.

Poole, Jane M.

Rose, Martin F.

Shreve, Elizabeth A.

Starn, J. Jeffrey

Stich, Bonnie J.

Taylor, Charles J.

Unthank, Michael D.

\section{HYDROLOGIC SURVEILLANCE}

SECTION

Rollins, Harry C.,

Assistant District Chief

Allen, H. Charles

Berlejung, R. Joseph

Bruenderman, Paul J.

Couts, Saundra J.
Eichert, D. Wayne

Evaldi, Ronald D.

Garcia, Rene

Griffin, Michael S.

Haliday, Amy D.

Hitchcock, Harry A.

Kloft, Loren G.

Martin, Gary R.

McClain, Dennis L.

McCombs, Gregory K.

Moore, Brian L.

Ottersbach, Paula L.

Pinkelton, Yolanda E.

Puckett, R. Edward

Ruhl, Kevin J.

Sholar, Clyde J.

Zettwoch, Douglas D.

Paducah Field Headquarters

Brown, Alan C.,

Supervisory Hydrologic Technician

Darnell, Roy S.

Filbeck, James D.

Hubbard, G. Lynn

Prestonsburg Field Headquarters

Hensley, Zeke

Williamsburg Field Headquarters

Byrd, F. Davis, Supervisory Hydrologic Technician

Dirrim, Anthony K.

Flannery, Tonya C.

Moses, Clifford R.

Pickard, Stephen B. 


\section{KENTUCKY DISTRICT FUNDING SOURCES}

Financial support for hydrologic data collection and investigations in Kentucky comes from the: (1) Federal-State Cooperative Program (COOP), where funds from local, regional, or State agencies and governments are matched with USGS funds; (2) transfer of funds from other Federal agencies (OFA); and (3) direct Congressional appropriations to the USGS (Federal) for hydrologic networks and investigative programs (referred to in this report as the USGS Federal Program). The sources of funding for District operations during Federal fiscal year 1993 are shown below and a list of cooperating agencies is shown on the following page.

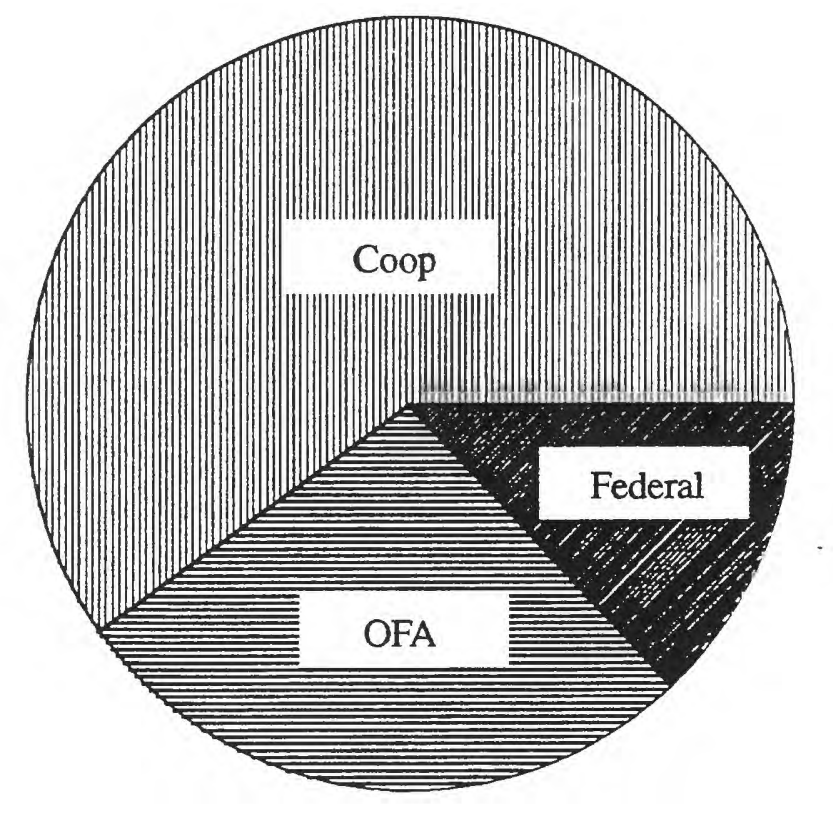

SOURCE OF FUNDING

때 Coop (60\%)

E OFA (27\%)

שII Federal (13\%) 
Agencies supporting water-resources activities in Kentucky:

Bullitt County, Kentucky

City of Campbellsville

City of Elizabethtown

City of Fulton

City of Georgetown

City of Lewisburg

Glasgow Water Company

Kentucky Air National Guard

Kentucky Natural Resources and

Environmental Protection Cabinet,

Department of Environmental Protection

-- Division of Water

-- Division of Waste Management

Kentucky State University
Kentucky Tourism Cabinet,

Department of Fish \& Wildlife Resources

Kentucky Transportation Cabinet

Kentucky Utilities Company

Louisville and Jefferson County

Metropolitan Sewer District

Owensboro Municipal Utilities

Public Service Indiana

Purchase Area Development District

University of Louisville

U.S. Army Corps of Engineers

U.S. Department of the Army

U.S. Environmental Protection Agency

U.S. Office of Surface Mining Reclamation 


\section{KENTUCKY DISTRICT PUBLIC-INFORMATION AND PUBLIC-SERVICE ACTIVITIES}

As part of the Kentucky District's responsibility to provide data and information on Kentucky's water resources to landowners, water users, public officials, business concerns, professional consultants, and the general public, District staff are involved in numerous other activities in addition to our regular programs of hydrologic data collection and investigations. Much of the daily activity involves providing information on a wide range of hydrologic, geologic, geographic, and environmental topics. District staff are also involved in public education. Staff routinely are asked to be guest speakers at primary and secondary schools and meetings of public interest groups, and serve as instructors and guest lecturers at colleges and universities. Staff members also coordinate the judging for the Environmental Section of the Annual Louisville Regional Science Fair and serve as judges for the Environmental and Earth Sciences Sections for science fairs held in the Louisville metropolitan area.

Equally important is the involvement of District staff as appointed members of advisory committees, task forces, and work groups of professional societies and Federal, State, or local governmental agencies. These include:

- Advisory Committee of the Ohio River Basin Commission

- American Society of Civil Engineers' Task Committee on Bridge Scour

- Committee on Research and Policy of the Kentucky Water Resources Research Institute

- Contributing Sponsor for the 1992 North American Benthological Society Meeting in Louisville, Kentucky

- Coordinating Committee for Mammoth Cave Agricultural Nonpoint Source Demonstration Project

- Federal Emergency Management Agency Interagency Flood Assessment Team

- Kentucky Ground-Water Advisory Council

- Kentucky Ground-Water Data Management Committee

- Kentucky Ground-Water Monitoring Guideline Committee

- Kentucky Natural Resources and Environmental Protection Cabinet Scholarship Committee

- Kentucky Rivers Assessment Advisory Committee

- Kentucky Soils Survey Work Planning Group

- Kentucky Water Availability Advisory Council

- Kentucky Water Interagency Coordinating Committee for Agricultural Nonpoint Source Pollution Prevention

- Nonpoint Source Advisory Committee of the Kentucky Division of Water

- Ohio River Basin Consortium for Research and Education

- Technical Review Committee for the Master Storm Water Management Plan of the Louisville and Jefferson County Metropolitan Sewer District

- U.S. Department of Agriculture Federal Interagency Review Group for Nonpoint Source Demonstration and Hydrologic Unit Projects 


\section{KENTUCKY DISTRICT HYDROLOGIC-DATA COLLECTION}

Hydrologic data, or basic data as they are commonly called, are critical to the investigations conducted by the USGS and other researchers. The basic data programs conducted by the Kentucky District provide streamflow, ground-water level, sediment, precipitation, water-quality, and water-use information essential for the management and protection of the State's water resources. The District's hydrologic data are available on computer disks and are published in the annual data report titled "Water Resources Data for Kentucky" and other publications.

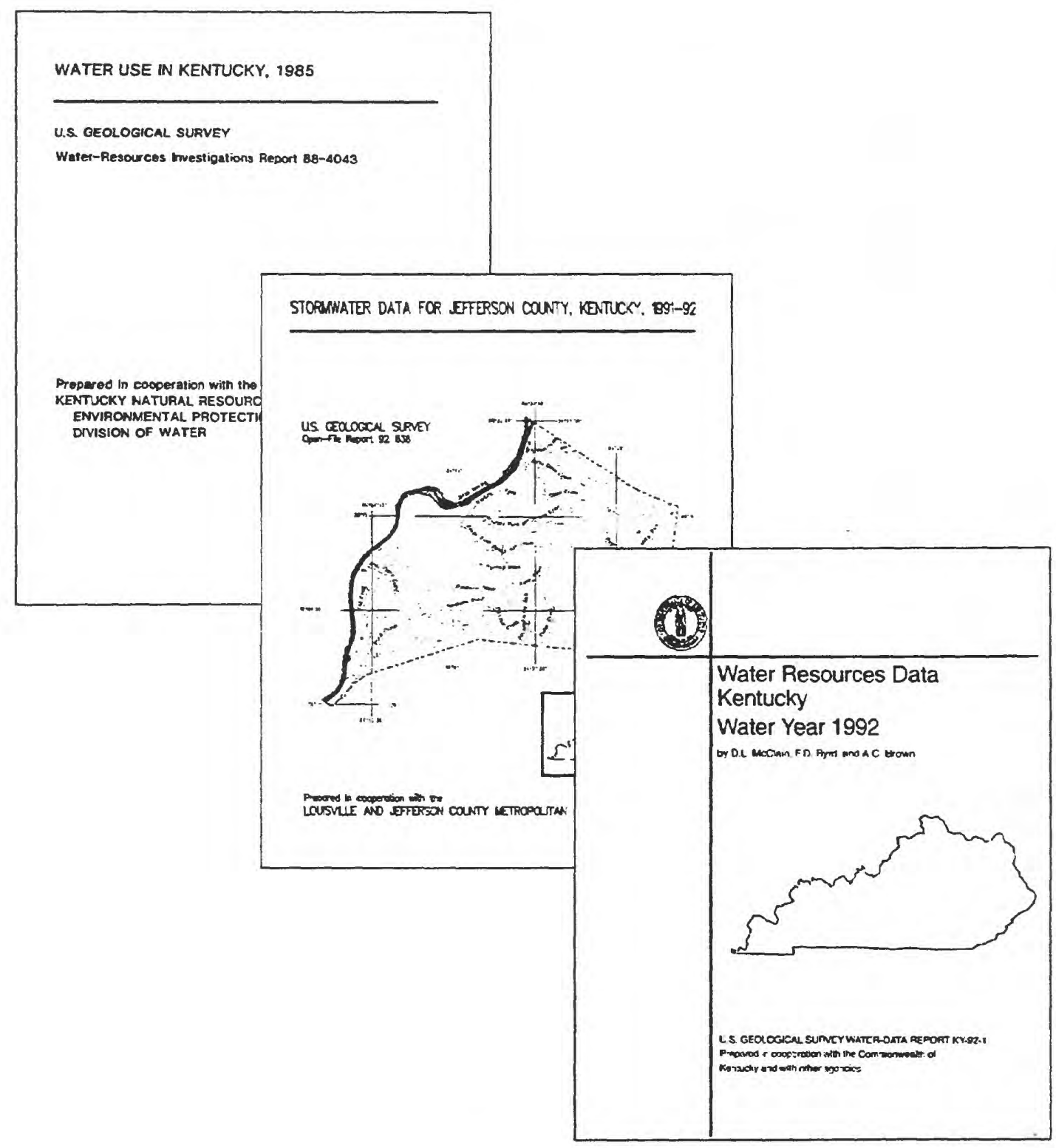




\section{Streamflow-Gaging Network}

(KY 00-001)

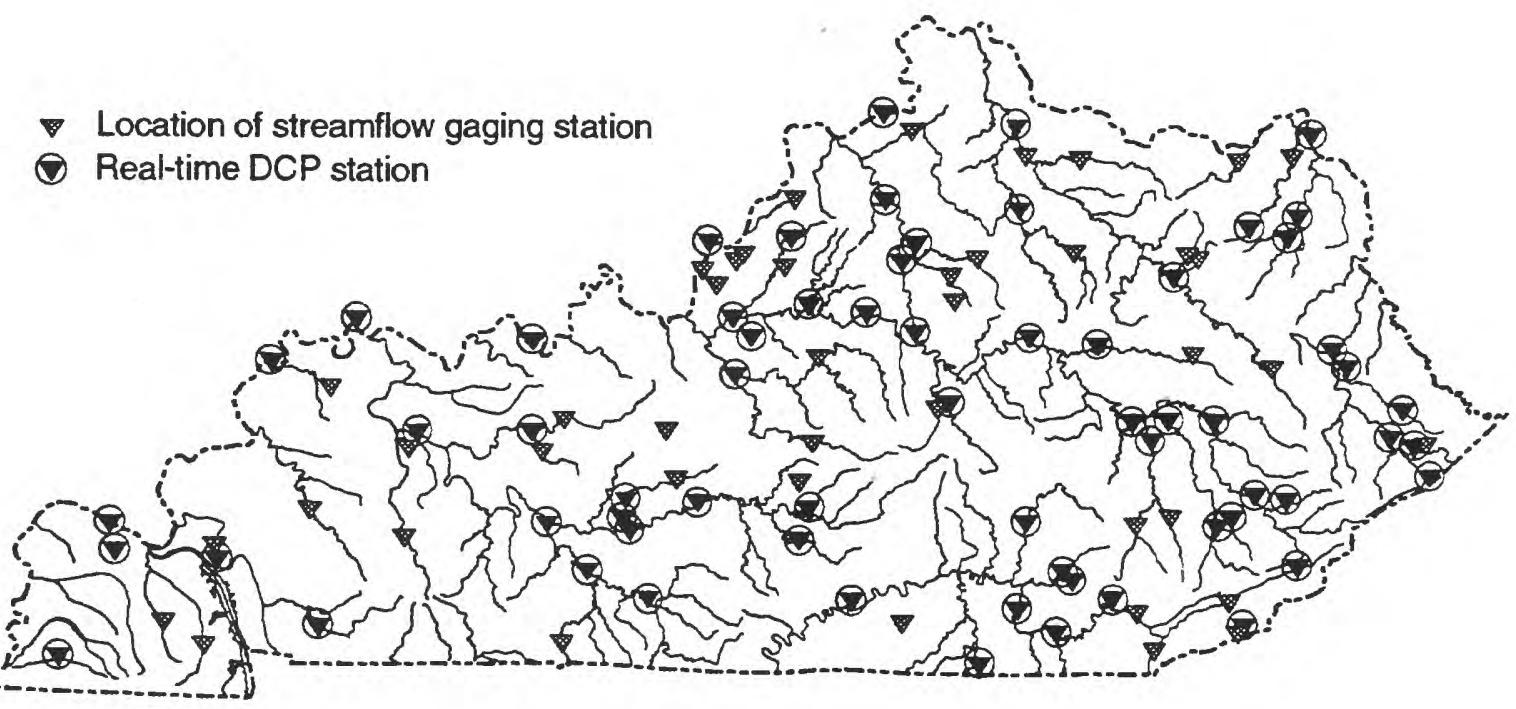

PROBLEM: Surface-water information is needed for surveillance, planning, design, hazard warning, operation, management, and protection purposes relevant to water supply, wasteload allocation, hydroelectric power, flood control, forecasting, irrigation, bridge and culvert design, fish and wildlife management, flood-plain management, and water-resources assessment and development. To provide this information, an appropriate surface-water data base is necessary.

\section{OBJECTIVES:}

1. Collect surface-water data sufficient to satisfy needs for current-purpose uses.

2. Collect data necessary for analytical studies to define for any location the statistical properties of, and trends in, the occurrence of water in streams, lakes, and reservoirs for use in planning and design.

3. Operate a network of real-time stations where surface-water data are transmitted by a datacollection platform (DCP) to Geostationary Operational Environmental Satellites (GOES) and received by ground stations which transmit the data to computers at the USGS and U.S. Army Corps of Engineers for current-purpose use and special studies.

FUNDING: Funding is provided by the Federal-State Cooperative Program, U.S. Army Corps of Engineers, and USGS Federal Program.

STATE COOPERATOR: Kentucky Division of Water

LOCAL COOPERATORS: Bullitt County

City of Campbellsville

City of Fulton

City of Georgetown

City of Lewisburg
Glasgow Water Company

Kentucky Utilities Company

Louisville and Jefferson County

Metropolitan Sewer District

Public Service Indiana

University of Louisville 


\section{Ground-Water-Level Observation Network}

(KY 00-002)

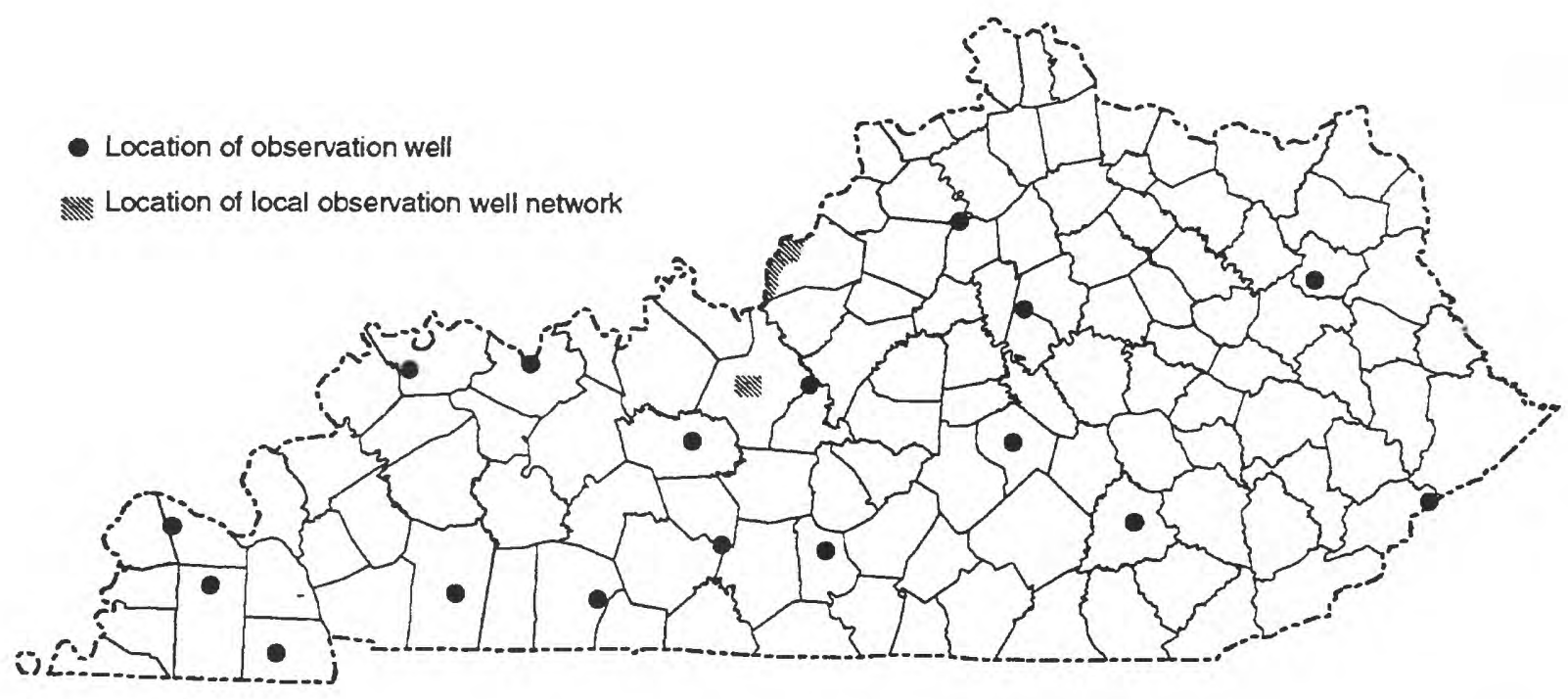

PROBLEM: Long-term ground-water-level data are needed to measure the effects of human activities and natural events, to assist in the prediction of future water supplies, and to provide data for the management and protection of the ground-water resource.

\section{OBJECTIVES:}

1. Collect ground-water-level data sufficient to provide a minimum, long-term data base so that the general response of the hydrologic system to natural (climatic) variations and human-induced stresses is known and potential problems can be defined early enough to allow proper planning, management, and protection.

2. Provide a data base against which short-term data acquired as part of areal and site-specific studies can be analyzed.

FUNDING: Funding is provided by the Federal-State Cooperative Program and the USGS Federal Program.

LOCAL COOPERATORS: Louisville and Jefferson County Metropolitan Sewer District City of Elizabethtown 


\section{Surface-Water-Quality Monitoring Network}

(KY 00-003)

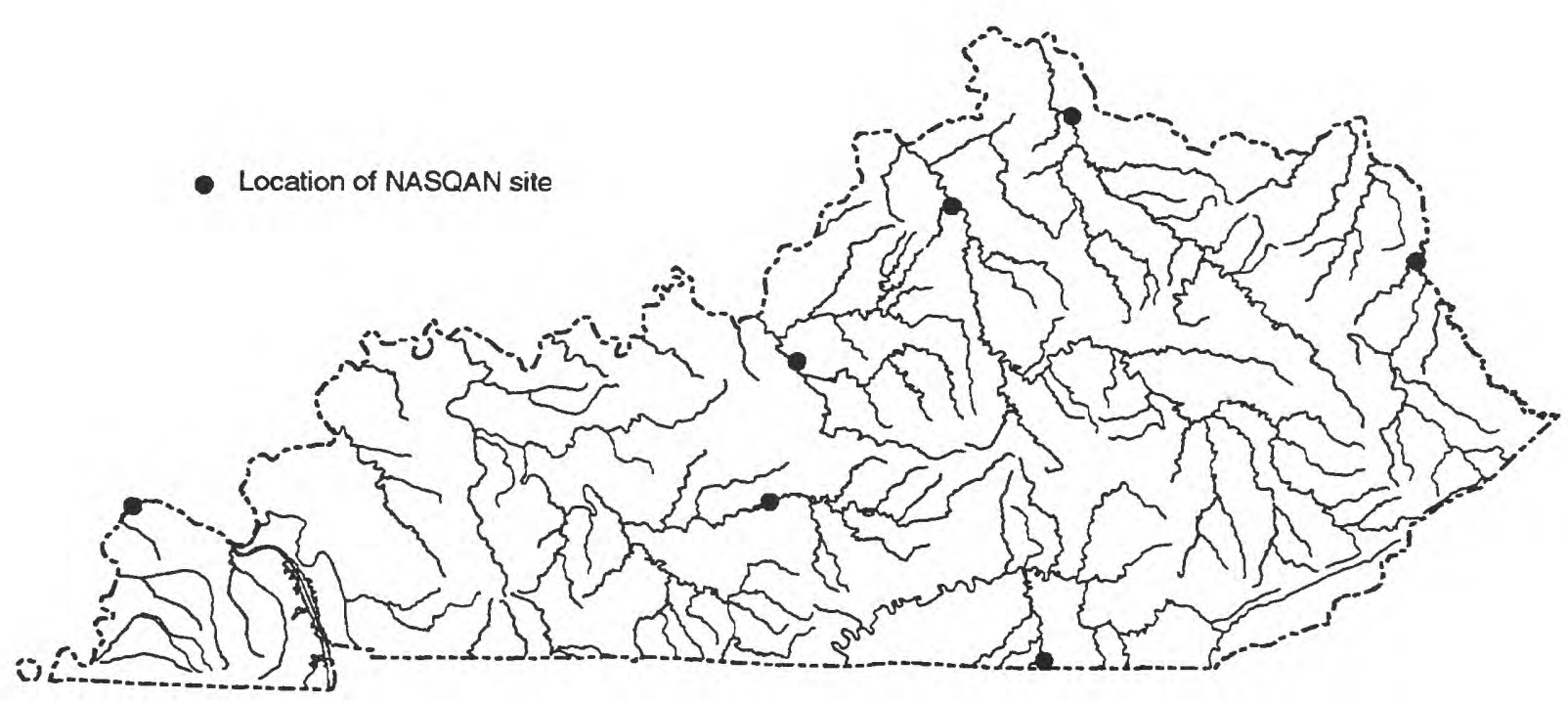

PROBLEM: Water-resource planning and water-quality assessment require a nationwide base level of standardized data. For the planning, management, protection, and assessment of the surface-water resource, the physical, chemical, and biological quality of the streams must be defined and monitored. The National Stream-Quality Accounting Network (NASQAN) is being implemented in Kentucky to provide such data.

\section{OBJECTIVES:}

1. Provide a National data base of surface-water quality information for use in broad Federal and State planning, management, protection, and assessment programs.

2. Provide data for State and Federal management of streams.

FUNDING: Funding is provided by the USGS Federal Program. 


\section{Suspended Sediment Monitoring Network}

(KY 00-004)

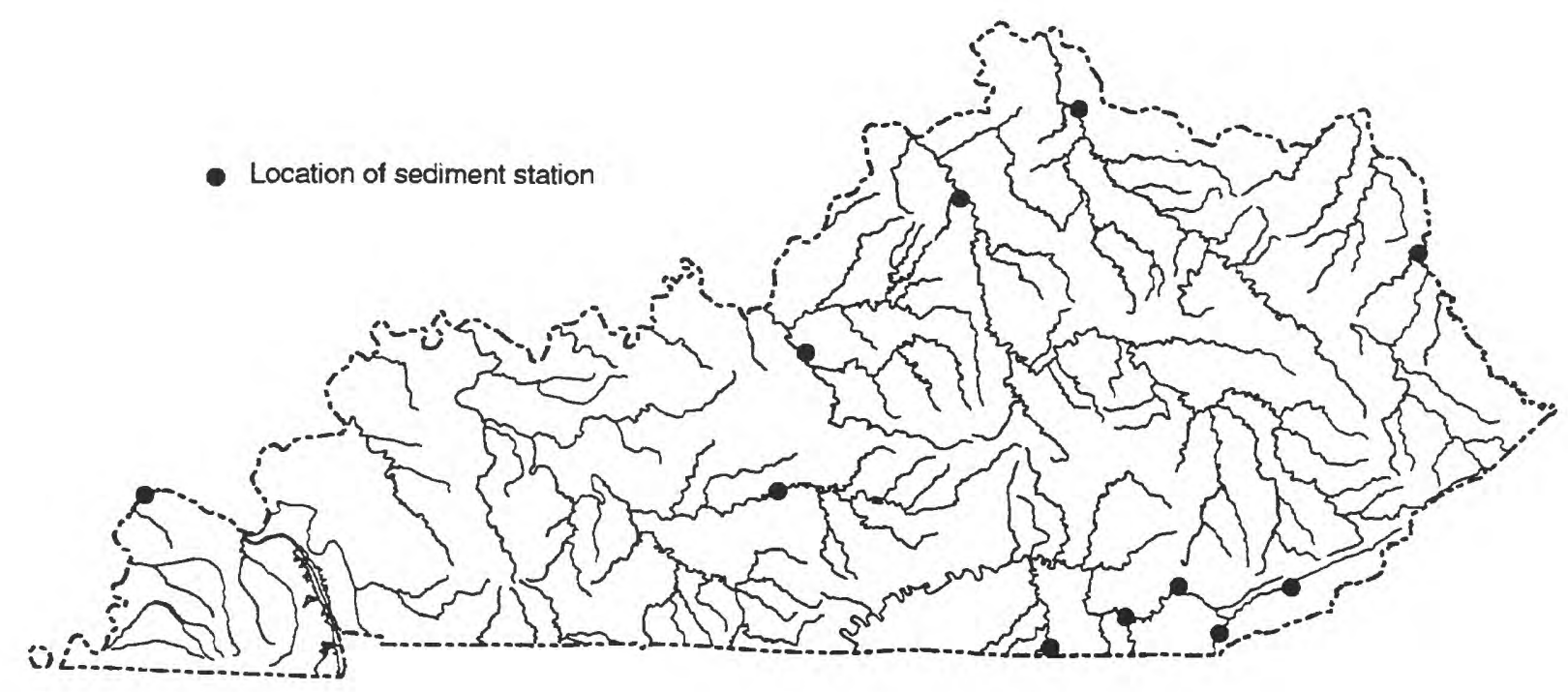

PROBLEM: Sediment plays an important role in the transport of constituents in surface-water and karst-aquifer systems. Concentrations of nutrients, trace elements, pesticides, and other constituents adsorbed to suspended sediments or streambed sediments are commonly several orders of magnitude higher than in the dissolved phase. Quantification of nonpoint source loads of constituents cannot be determined without definition of suspended-sediment and streambed-sediment loads. Water-resource management and protection efforts require a nationwide data base of standardized sediment data.

\section{OBJECTNES:}

1. Collect and publish suspended-sediment data.

2. Contribute to a national data base of suspended-sediment data.

FUNDING: Funding is provided by the U.S. Army Corps of Engineers and the USGS Federal Program. 


\section{Water Use}

\section{(KY 79-007)}

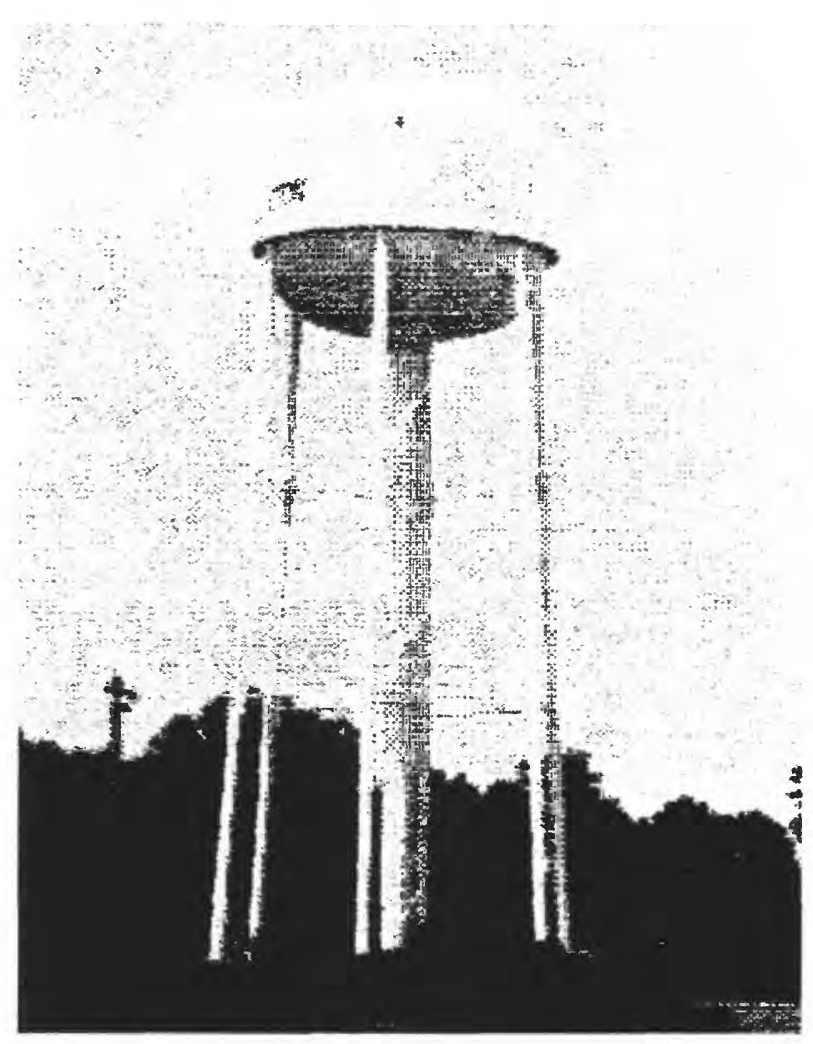

PROBLEM: The water resources of Kentucky are used more extensively with each passing year. Although information has been developed about the occurrence and quality of the resource, relatively little has been done to describe where, how, and in what quantities water is being used. Without such information, decision makers cannot resolve critical problems related to water demand and allocation, water quality, environmental impact, and energy development.

\section{OBJECTIVES:}

1. Determine the quantity of surface and ground water that is withdrawn and its uses, the quantity of water consumed during use, and the quantity of water returned to streams and aquifers after use.

2. Update a computerized statewide water-use data base.

3. Publish reports of water use in Kentucky.

FUNDING: Funding is provided by the Federal-State Cooperative Program.

STATE COOPERATOR: Kentucky Division of Water 


\section{Chemical Quality of Precipitation}

(KY 84-005)

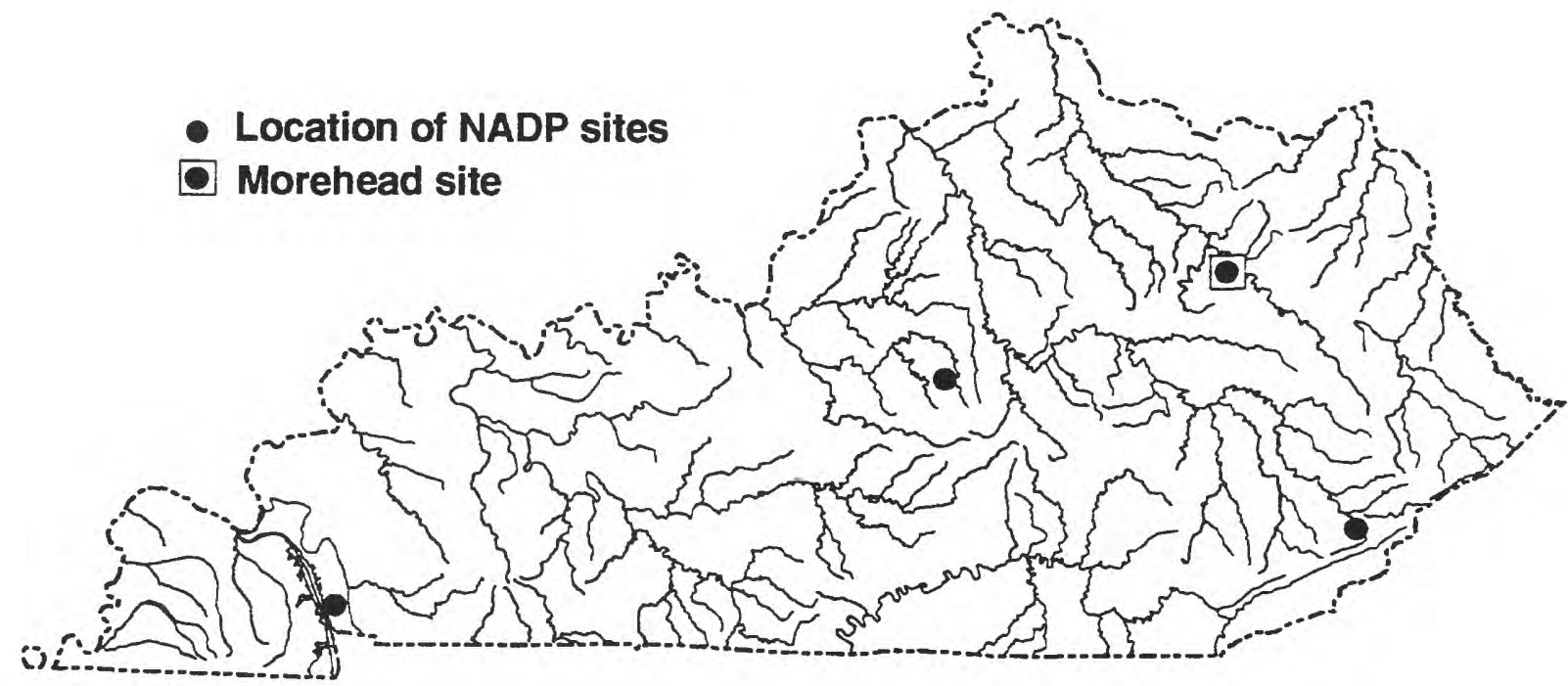

PROBLEM: The amount of substances dispersed in the atmosphere and deposited by precipitation is a potentially significant nonpoint source of water contamination. Thus, there is a need for reliable and long-term measurements of chemical constituents in precipitation. Such measurements are essential for responsible management of the agricultural, forest, and aquatic-ecosystem resources of the Nation. The National Atmospheric Deposition Program (NADP) was established for the purpose of conducting research on atmospheric deposition and its effects on water resources, agriculture, and forest lands in cooperation with Federal, State, and private research agencies. The USGS is participating in this program as part of the National Trends Network (NTN). Four stations are maintained in Kentucky with the station near Morehead being maintained by the Kentucky District.

\section{OBJECTIVES:}

1. Collect and publish chemical data for precipitation.

2. Document variations and trends in the quality of precipitation.

FUNDING: Funding is provided by the USGS Federal Program. 


\section{KENTUCKY DISTRICT HYDROLOGIC INVESTIGATIONS}

A wide-ranging program of hydrologic investigations and research provides information essential to the protection and management of the water resources of Kentucky. Investigations cover, to some degree, all aspects of hydrology, water quality, and aquatic biology. The results of hydrologic investigations are presented in USGS publications, scientific journals, and at scientific meetings.

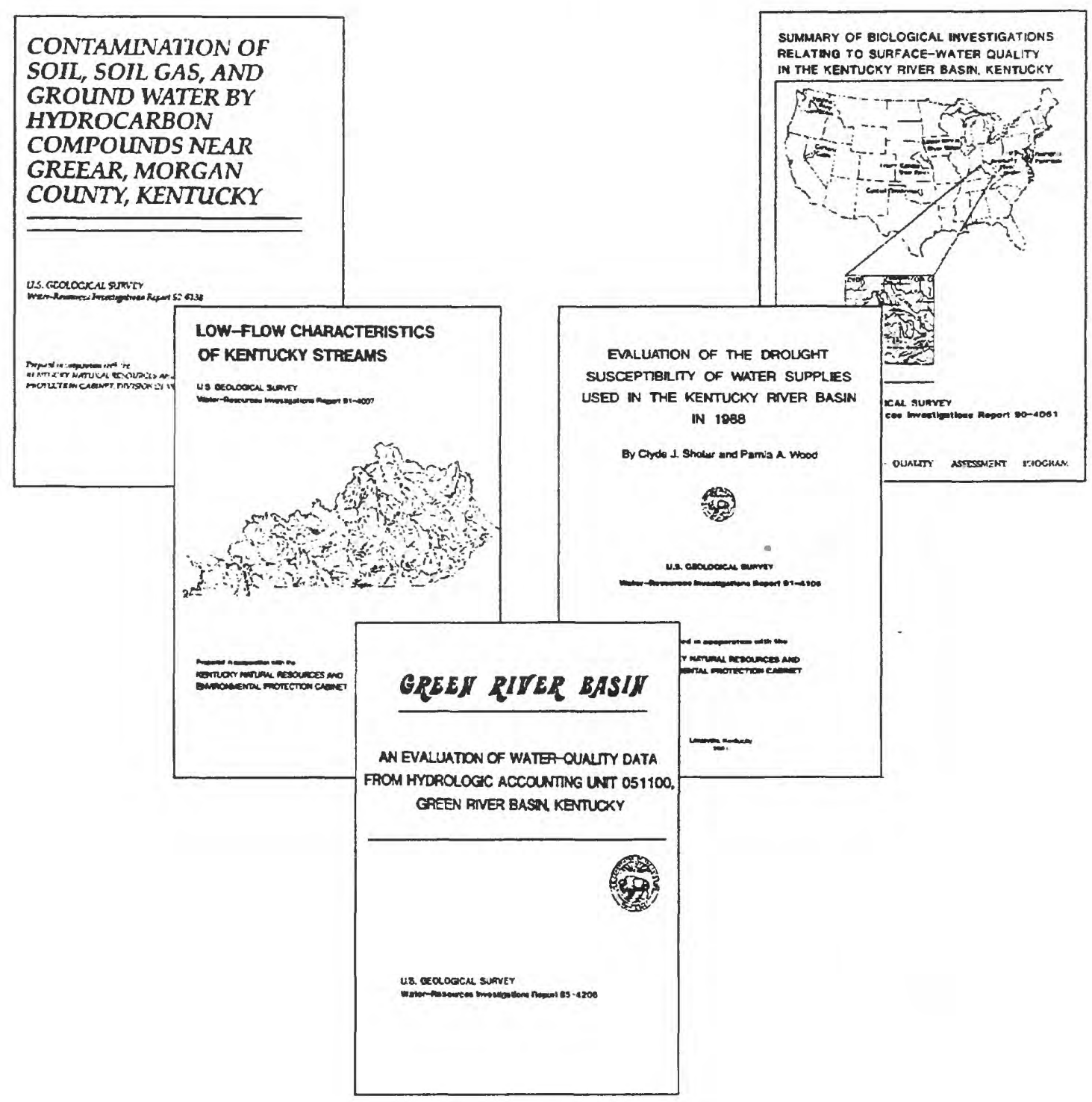




\section{National Water-Quality Assessment \\ Program -- Kentucky River Basin}

(KY 86-071)

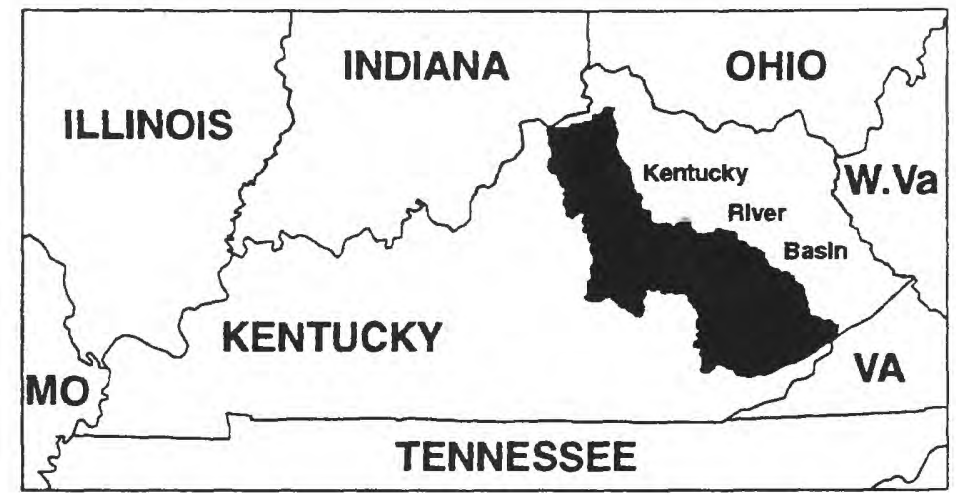

PROBLEM: The protection and enhancement of the quality of the Nation's water resources has become a priority concern, and as a result of this concern, water-quality programs have been implemented at the Federal, State, and local levels. Water management and protection decisions, which often involve the construction of waste-treatment facilities and assessment of the likely effects of contemplated changes in land- and water-management practices, are currently being made based on limited scientific information. Further, it has been difficult to scientifically evaluate the effectiveness of management and protection programs. Effective decision making requires adequate information and understanding of current water-quality conditions and trends. To meet this need, the USGS established the National Water-Quality Assessment (NAWQA) Program, with the Kentucky River basin selected as one of seven pilot studies to test and refine concepts for the program. This basin is the most densely populated river basin in the State. Surface-water quality is affected by wastewater discharges and a variety of nonpoint sources of contaminants, including agricultural and urban stormwater runoff, coal mining, oil production, landfills, and atmospheric deposition.

\section{OBJECTIVES:}

1. Provide a nationally consistent description of current water-quality conditions for a large part of the Nation's water resources.

2. Define long-term trends (or lack of trends) in water quality.

3. Identify, describe, and explain, to the extent possible, the major factors that affect observed waterquality conditions and trends in the Kentucky River Basin.

FUNDING: Funding is provided by the USGS Federal Program. 


\section{Regionalization of Low-Flow Characteristics of Kentucky Streams}

(KY 86-072)

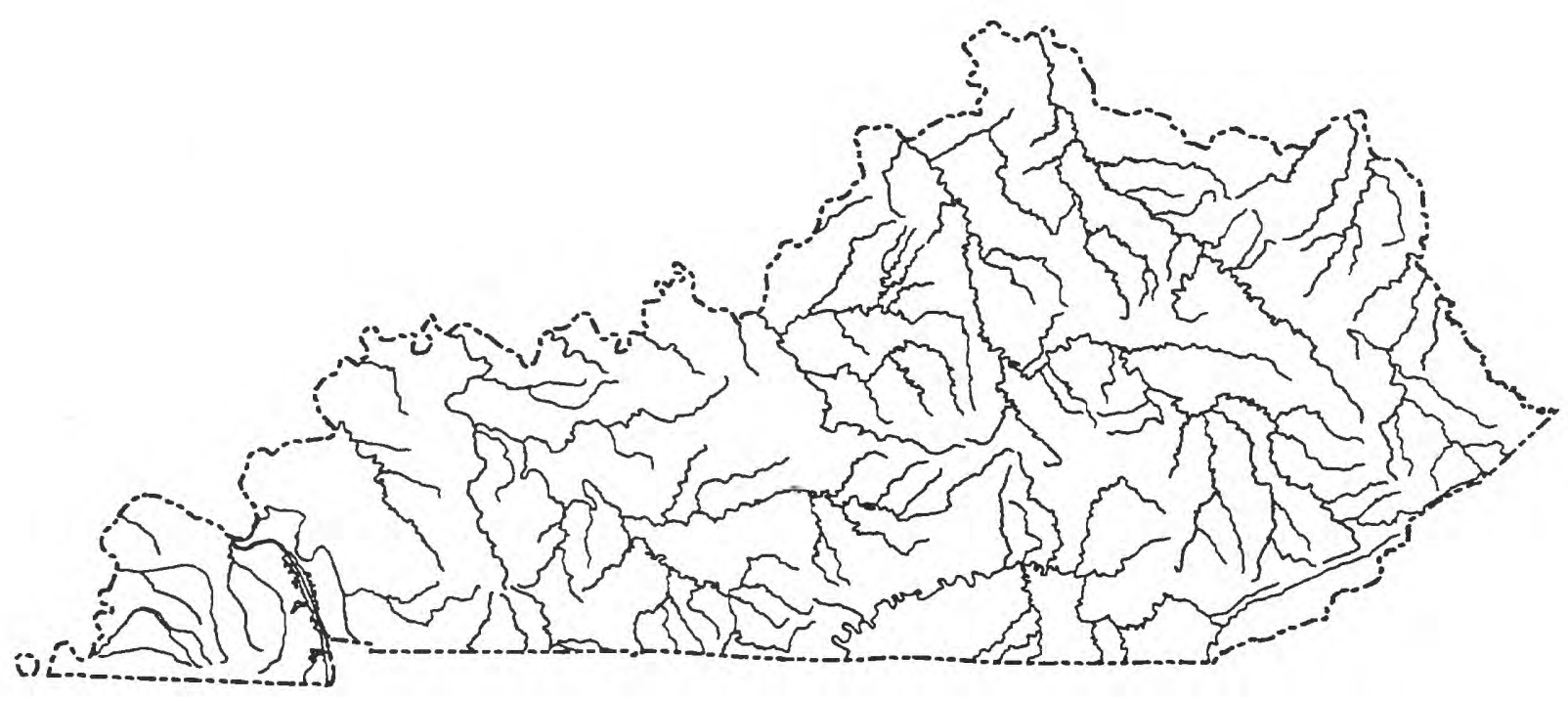

PROBLEM: Knowledge of low-flow characteristics of Kentucky streams is critical for the proper management and protection of the resource. Low-flow information is needed for the allocation of wasteloads to receiving streams and for estimating the availability of surface water for competing domestic, agricultural, and industrial uses as well as for supporting recreation and stream ecology. Commonly, wastewater discharge limits and water-supply criteria are based on the 7-day, 10-year lowflow frequency value (7Q10). Presently, the amount and type of low-flow data collected in Kentucky are inadequate. Low-flow data at partial-record sites throughout Kentucky are needed to supplement streamflow information collected on a continuous basis.

\section{OBJECTIVES:}

1. Operate a statewide low-flow data-collection network.

2. Update low-flow statistics for the continuous-record gaging stations for unregulated streamflow periods and for the low-flow partial-record sites.

3. Develop techniques to estimate these low flows for ungaged stream sites in Kentucky.

FUNDING: Funding is provided by the Federal-State Cooperative Program.

STATE COOPERATOR: Kentucky Division of Water 


\section{Geographic Information System Data Base for Hydrologic Research}

(KY 89-077)

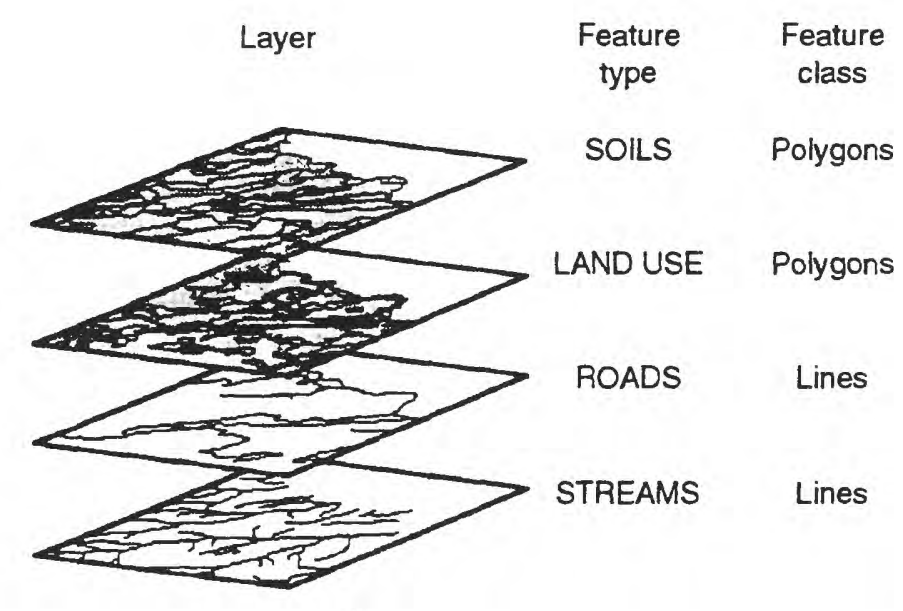

PROBLEM: Hydrology is a study that integrates many areas of natural resources and human activities. As such, hydrology uses many types of information from diverse sources in differing scales and formats. The demand is rapidly growing for digital data bases and for the computer software to store and integrate this information. A geographic information system (GIS) is a computer software system that can assemble and analyze diverse data, using location as the common reference point. The need exists to assemble such information using GIS, focusing on hydrologic features, to assist in modeling, mapping, data storage and management, interactive display and query, and interpretation. GIS technology is a powerful tool for Federal, State, and local agencies and water managers in performing land- and water-resource assessments, for problem identification and assessment, and for resource planning, protection, and management.

\section{OBJECTIVES:}

1. Integrate a GIS with existing data base systems.

2. Manage, update, and maintain a hydrology-related GIS data base for Kentucky.

3. Test and demonstrate methods and procedures for compilation, display, and analysis using GIS.

4. Develop techniques to advance and support water-resources research and the use of GIS.

FUNDING: Funding is provided by the Federal-State Cooperative Program.

LOCAL COOPERATORS: University of Louisville Purchase Area Development District 


\section{Hydrologic Assessments at Leaking Underground Storage Tank Sites}

(KY 89-079)

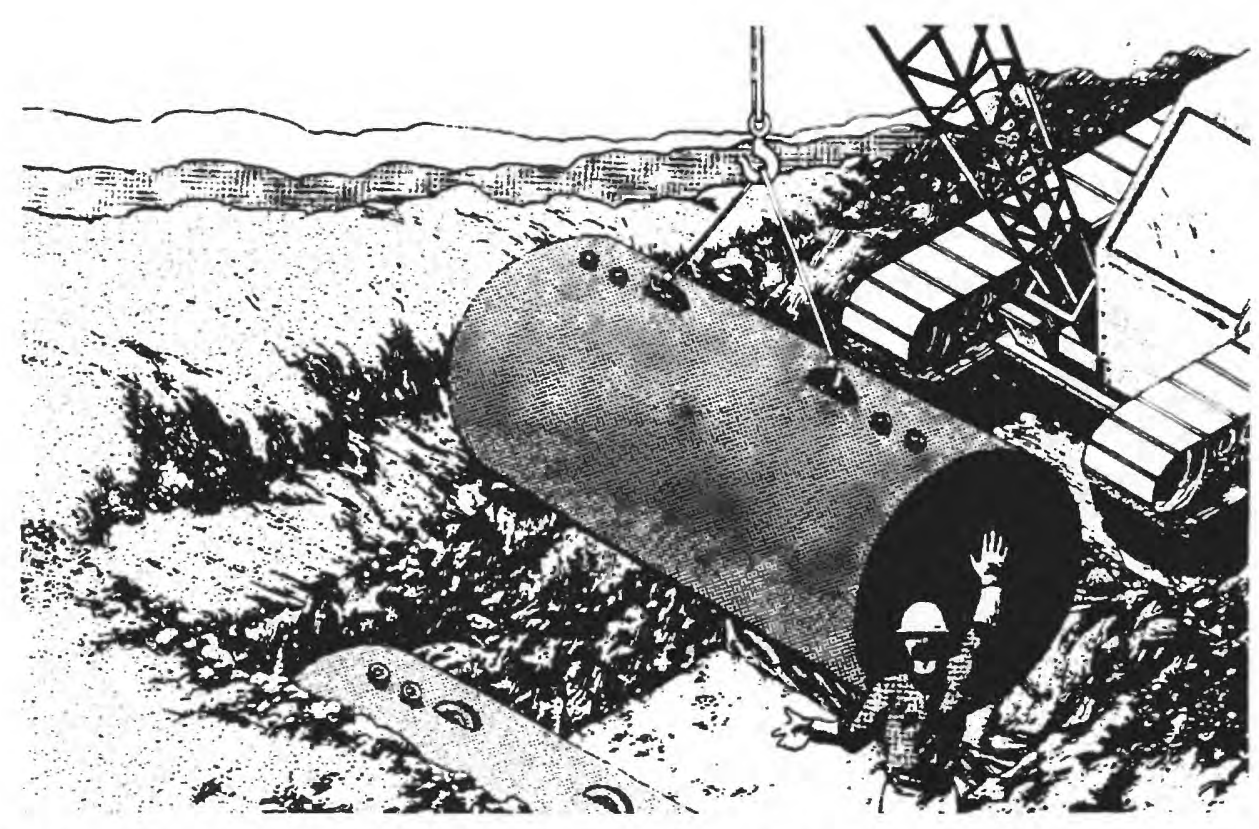

PROBLEM: The U.S. Environmental Protection Agency has estimated that thousands of underground storage tanks are leaking or will leak. In response to the 1984 Subtitle I Amendment to the Resource Conservation and Recovery Act, the Kentucky Division of Waste Management (KDWM) initiated a program to regulate underground storage tanks used to store petroleum products or other hazardous chemicals. The KDWM has requested technical assistance from the USGS in addressing hydrologic issues related to leaking underground storage tanks. The USGS provides a wide range of technical support to the KDWM. Such support can include but is not limited to:

- Geologic coring, drilling of monitoring wells, and installation of piezometers

- Soil, ground-water, and surface-water-quality sampling

- Water-level measurements, streamgaging, and surveying

- Design, implementation, and interpretation of aquifer tests

- Use of qualitative or quantitative dye-tracer tests to define directional trends or solutetransport characteristics of ground-water flow in karst and fractured-rock terranes

\section{OBJECTIVES:}

1. Locate and confirm the source of hydrocarbon compounds and other hazardous chemical contamination at underground storage tank sites.

2. Determine the degree and extent of contamination.

3. Assess the effect of such contamination on the quality of soils, ground water, surface water, and streambed sediments in the vicinity of underground storage tank sites.

FUNDING: Funding is provided by the Federal-State Cooperative Program.

STATE COOPERATOR: Kentucky Division of Waste Management 


\section{Urban Hydrology and Surface-Water Quality of Jefferson County \\ (KY 90-084)}

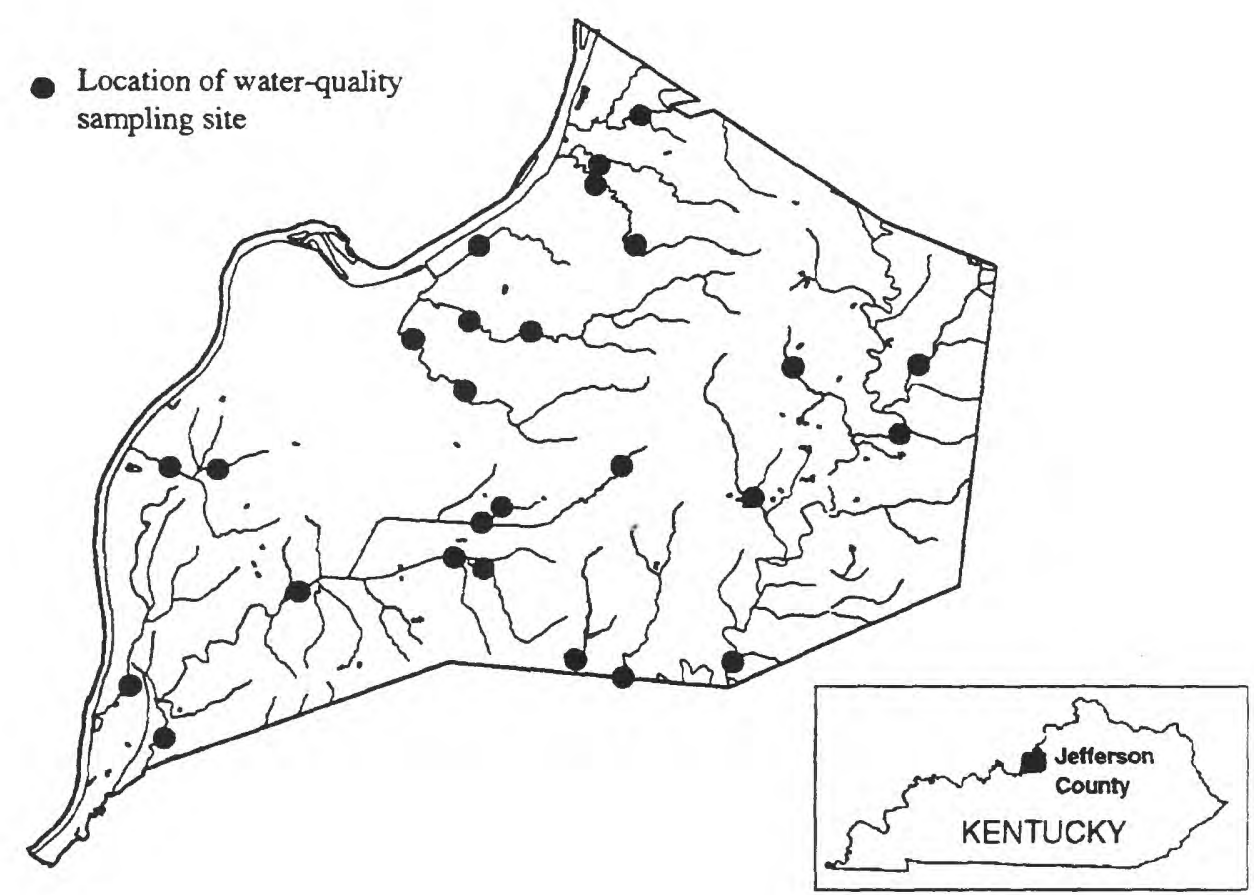

PROBLEM: Jefferson County is experiencing increased urban development. As urbanization progresses, rural land is being developed for residential, commercial, and industrial purposes. Such development increases the potential for flooding and increases the types and quantities of contaminants being released to the urban streams from a variety of point and nonpoint sources, including effluents from domestic and industrial wastewater treatment plants, stormwater runoff, and leachates from septic tanks, surface impoundments, and landfills. Diverse hydrologic data are needed to define streamflow characteristics; to define current water-quality conditions throughout the range of flow conditions and seasons; to evaluate the effectiveness of flood-protection, water-management, and water-quality protection programs; and to evaluate contemplated changes in land- and water-management practices.

\section{OBJECTIVES:}

1. Collect rainfall, streamflow, and surface-water-quality data as part of a comprehensive, long-term hydrologic network.

2. Collect stormwater runoff quality data.

3. Use the resulting hydrologic data with an interpretation of urban stream hydrologic and waterquality conditions to define the relation between land use and the quality of urban stormwater runoff.

FUNDING: Funding is provided by the Federal-State Cooperative Program.

LOCAL COOPERATOR: Louisville and Jefferson County Metropolitan Sewer District 


\section{Hydrologic Investigation of Stress-Relief Fractures of a Steep-Sloped Valley in the Coal Areas of Eastern Kentucky}

(KY 90-086)

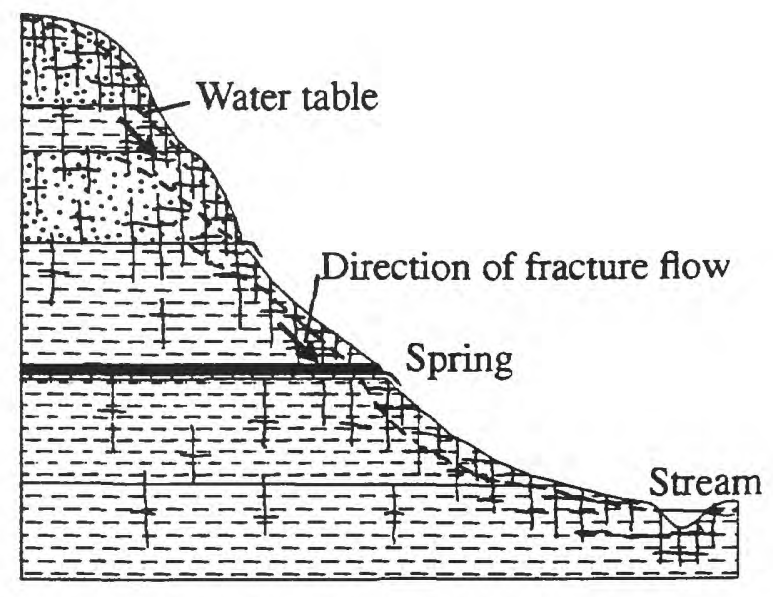

PROBLEM: The characteristics of ground-water movement down steep-sloped valley walls in the coal-bearing rocks of eastem Kentucky and in similar areas of the Appalachian Plateaus and Valley and Ridge Provinces of the eastern United States are poorly understood. Research has shown that stressrelief fractures, both natural and caused by underground mining, constitute the most transmissive part of the aquifer systems and significantly affect the hydrology of the valleys in these areas. Previous USGS investigations of a fracture-flow aquifer system near Fishtrap Lake in Pike County have shown that ground water in rocks underlying the Eastern Kentucky Coal Field can move from areas of higher head to areas of lower head through various permeable zones thought to be hydrologically isolated. Results of dye-tracer tests indicate that underground coal mining and subsequent subsidence in the mined-out seam have altered the natural ground-water flow system. There are limited data to describe the hydraulic properties of the fracture zone and the nature of ground-water flow beneath hillsides and valleys where these fractures occur.

\section{OBJECTIVES:}

1. Better define the extent of inter-fracture connections between hilltops and valleys in a steep-slope, coal-bearing terrane.

2. Better define the velocity of dye movement down a steep slope in coal-bearing rocks.

3. Ascertain if dye injected during a previous study was diverted to an abandoned underground coal mine and then discharged through mine drainage at some distance from the injection site and monitoring wells.

4. Use results of dye-tracer tests to better define the hydraulic properties of the fracture zones.

FUNDING: Funding is provided by the U.S. Office of Surface Mining Reclamation and Enforcement. 


\section{Geohydrologic Mapping of the Recharge Areas of Municipal Water-Supply Springs in a Karst Terrane Near Elizabethtown}

(KY 90-087)

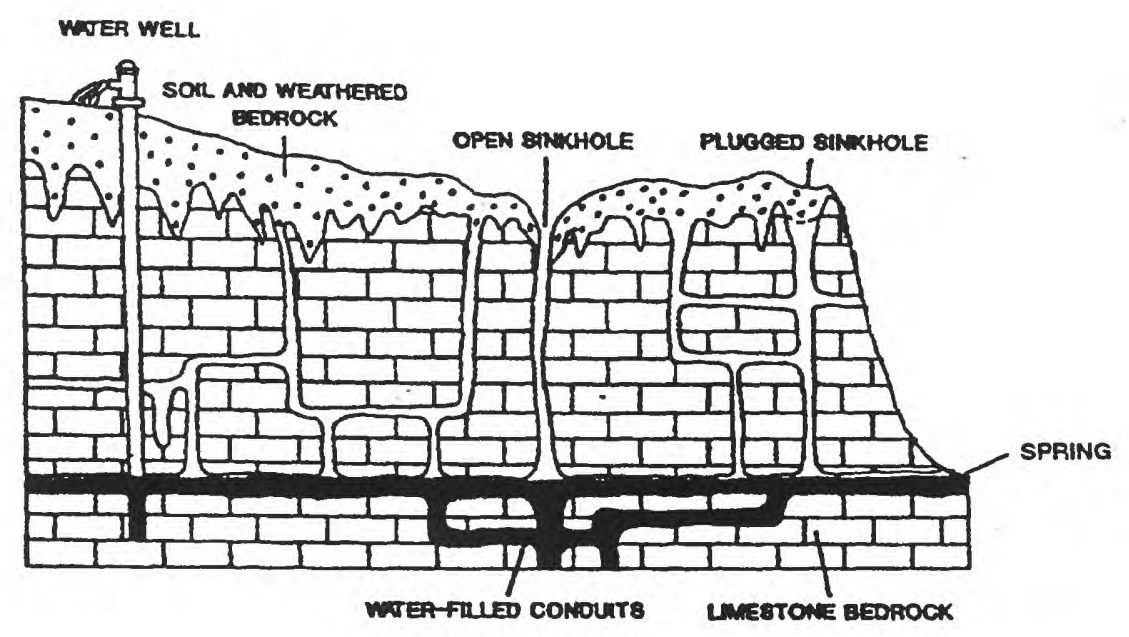

PROBLEM: In Kentucky, many public and private water supplies are obtained from springs discharging from karstified bedrock. Karst springs are the outlets of subsurface drainage systems that consist of dissolutionally enlarged fractures and pipe-like openings known as conduits. Recharge to the conduit network within a karst ground-water basin occurs through the relatively direct and rapid infiltration of precipitation and surface runoff by way of sinkholes and sinking streams. Consequently, karst aquifers are especially vulnerable to contamination. If the quality of a spring-based water supply is to be protected, the recharge area of the spring must be delineated, and the potential sources of contamination within the recharge area must be identified and controlled. City Spring and Gaithers Spring are the principal sources of water for the City of Elizabethtown, serving a population of approximately 12,500 . This is the second largest public water supply in the State relying on springs.

\section{OBJECTIVES:}

1. Demonstrate geohydrologic mapping techniques, including ground-water tracing studies, for the identification of interconnections between sinkholes and springs.

2. Locate and map the physical boundaries of the karst ground-water basin drained by each watersupply spring.

FUNDING: Funding is provided by the Federal-State Cooperative Program.

STATE COOPERATOR: Kentucky Division of Water 


\section{Pilot Project to Update the Kentucky Hydrologic Investigations Atlases}

(KY 90-088)

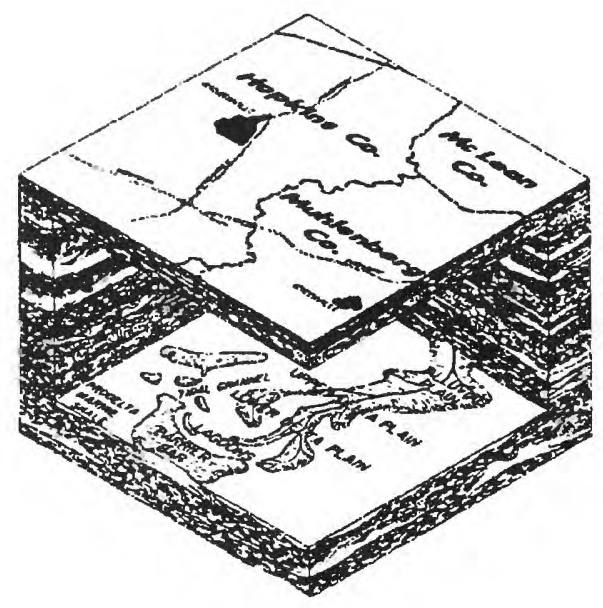

PROBLEM: Ground-water appraisals for the entire State have been published by the USGS as a series of Hydrologic Investigations Atlases (HA's). The HA's for the alluvial aquifer along the Ohio River and the aquifer system in the Jackson Purchase Region are fairly detailed and are based on a large number of inventoried wells and springs and detailed geologic-quadrangle maps (GQ's). Other HA's that cover large areas of the State, are based on limited well and spring inventory data, and were published before the detailed GQ's were completed. The inventories, mostly conducted in the 1950's, generally included sparse quantitative data on aquifer hydrologic and water-quality characteristics. Since the publishing of the HA's, additional research has defined the ground-water resources in selected areas of the State; however, there has not been a comprehensive effort to update the well and spring inventory data. State, local, and Federal water-management and protection agencies need comprehensive, up-to-date information on the ground-water resources of Kentucky.

\section{OBJECTIVES:}

1. Illustrate the use of data from an up-to-date inventory of wells and springs, GQ's, and recent ground-water studies to better define the water-bearing characteristics of geologic units.

2. Enhance the ground-water-quality data base for the pilot study area.

3. Ilustrate the use of geographic information system (GIS) technology, which will be used to generate the map products for the pilot study area, to enhance the analysis and presentation of the data.

4. Provide the basis for determining the feasibility and desirability of updating other HA's in Kentucky.

FUNDING: Funding is provided by the Federal-State Cooperative Program.

STATE COOPERATOR: Kentucky Division of Water

LOCAL COOPERATOR: University of Louisville 


\section{Fate and Transport of Agricultural Chemicals}

(KY 90-089)

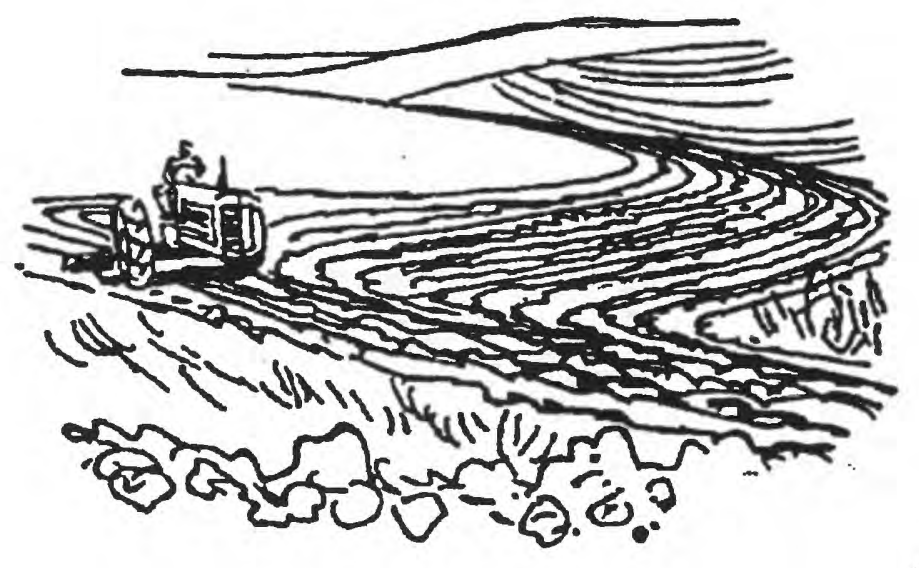

PROBLEM: Agriculture is a major nonpoint source of surface- and ground-water contamination in many parts of the Nation, including Kentucky. However, the extent of the problem including the occurrence, distribution, fate, and transport of agricultural chemicals, especially pesticides and nutrients, have not been defined. Further, the effectiveness of best management practices (BMP's) for improving the quality of surface and ground water affected by agricultural activities has not been fully documented. Therefore, the USGS, in cooperation with Kentucky State University (KSU), is conducting research for the purpose of describing and assessing hydrologic effects and processes associated with agricultural management practices with emphasis on sustainable agricultural practices.

\section{OBJECTIVES:}

1. Instrument test plots where various agricultural chemicals have been applied at the KSU Research Farm for the collection of climatological and soil-moisture data, stormwater runoff, and soil-water samples.

2. Test the effectiveness of selected BMP's for soil management and the protection of surface- and ground-water quality.

3. Develop soil/water partitioning coefficients of selected herbicides in clay loam soil.

4. Evaluate the utility of a leaching model for predicting herbicide movement through the unsaturated zone.

FUNDING: Funding is provided by the USGS Federal Program and Kentucky State University.

STATE COOPERATOR: Kentucky State University 


\section{Determination and Regionalization of Harmonic-Mean Flows for Streams}

(KY 90-090)

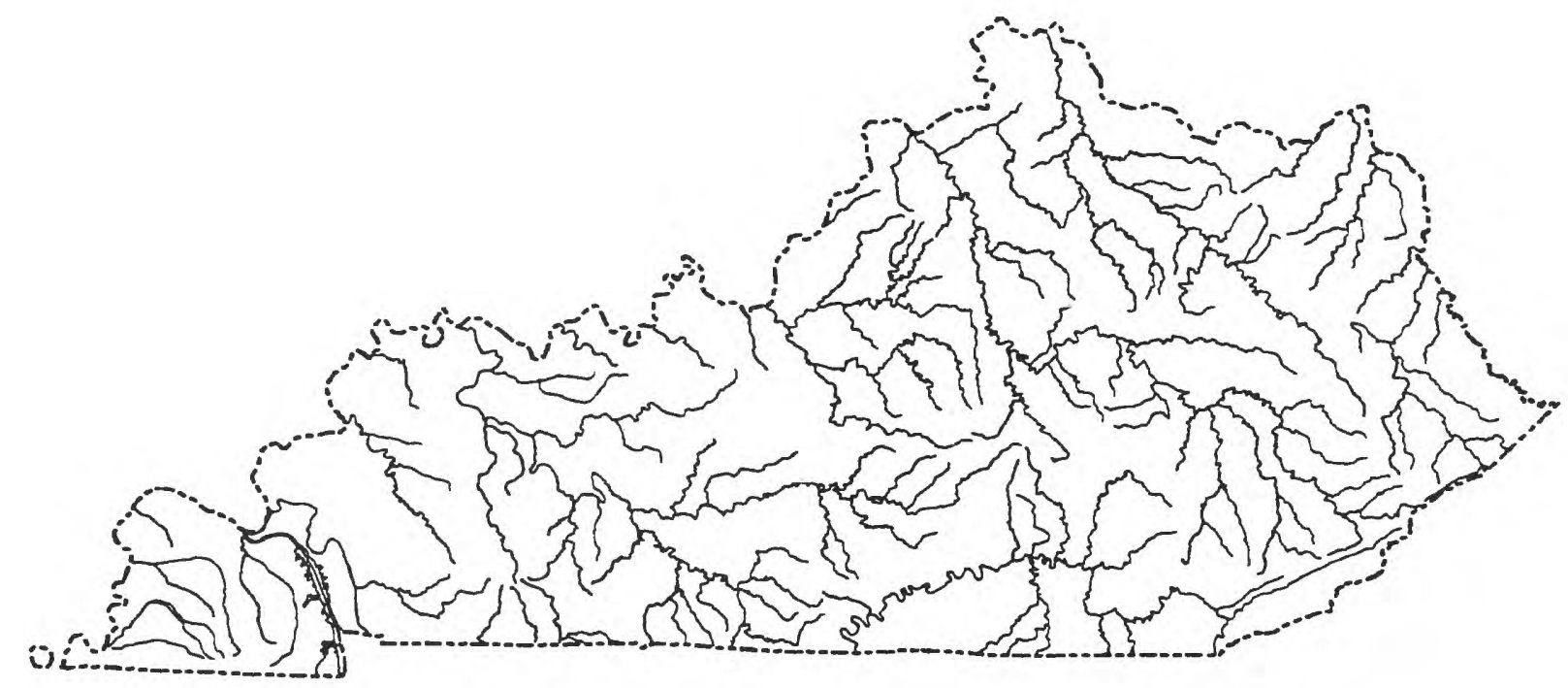

PROBLEM: The Kentucky Natural Resources and Environmental Protection Cabinet has established allowable, in-stream concentration limits, called water-quality criteria, for surface waters. Human-health criteria for toxic substances are based on nationally developed numerical criteria and associated risk factors. In 1990, the Kentucky Division of Water adopted the use of a statistic known as the harmonic-mean streamflow as the governing "design" flow for establishing point-source discharge limits for substances having human-health water-quality criteria. Adoption of this statistic was based on the conclusion that this value can provide the most representative estimate of long-term average, in-stream exposure concentrations of these substances. Values for the harmonic-mean streamflow are needed for all streams in Kentucky for the protection of the water resource.

\section{OBJECTIVES:}

1. Analyze available data from the streamflow-gaging network, located in and adjacent to Kentucky, to estimate long-term harmonic-mean streamflow values at streamflow-gaging stations, for both regulated and unregulated periods of record.

2. Develop a procedure for estimating the harmonic-mean streamflow value at ungaged stream sites not affected by regulation or local diversions.

FUNDING: Funding is provided by the Federal-State Cooperative Program.

STATE COOPERATOR: Kentucky Division of Water 


\section{Assessment of the Effectiveness of Best \\ Management Practices to Control Quality of Highway Runoff}

(KY 90-091)

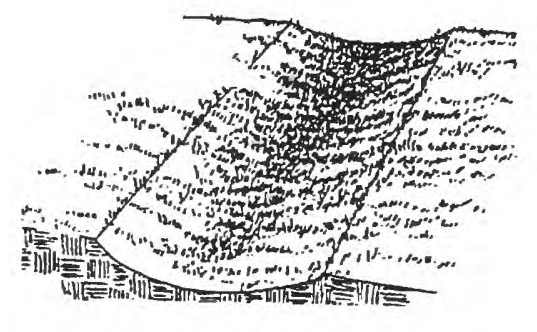

Grassed Waterway

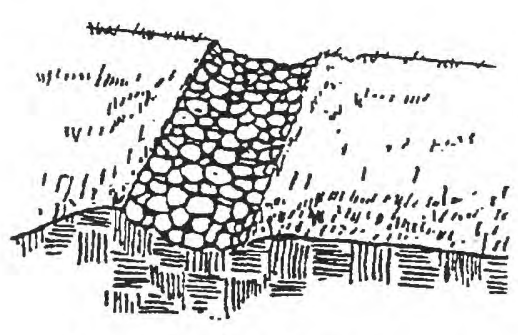

Riprap-Lined Drainageway

PROBLEM: Road surface contaminants, specifically trace elements, oil and grease, and other trace organics, are deposited from many sources within urbanized areas. These contaminants are subsequently carried to streams during storm events. Investigations have been conducted to evaluate the effectiveness of best management practices (BMP's) to improve the quality of the surface runoff before the runoff enters a stream. However, similar studies have not been conducted to characterize the quality of highway runoff and evaluate the effectiveness of BMP's to minimize ground- and surfacewater-quality effects in less urbanized and rural areas in karst terrane. The research is being performed in Georgetown.

OBJECTIVE: Evaluate the effectiveness of selected BMP's for highway runoff for protecting water quality in karst terrane.

FUNDING: Funding is provided by the U.S. Environmental Protection Agency.

STATE COOPERATOR: Kentucky Transportation Cabinet 


\section{Investigation of Potential Environmental \\ Contamination at the Kentucky Air National \\ Guard Facility, Standiford Field}

(KY 90-092)

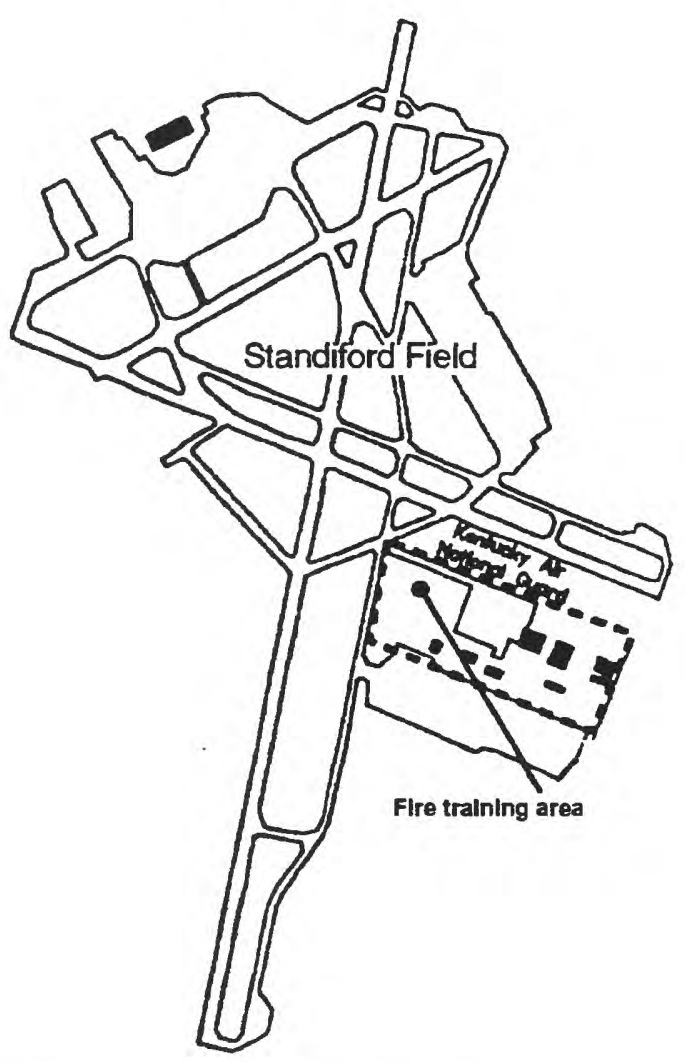

PROBLEM: Past operations of the 123rd Airlift Wing of the Kentucky Air National Guard, Standiford Field, in Louisville have involved the use of hazardous materials and waste. A preliminary assessment, conducted under the Installation Restoration Program, identified a fire training area (used from 1958-72) as being potentially contaminated with JP-4 fuel, gasoline, solvents, and strippers containing methylethylketone, methylisobutylketone, and trichloroethane. The proximity of the fire training area to several small karst springs and a wetland may have resulted in these sites being a collection area for the contaminants.

\section{OBJECTIVES:}

1. Determine if surface water, ground water, soils, or stream sediments are contaminated near the fire training area.

2. Determine the degree and extent of any contamination.

3. Assess the effect of such contamination on the quality of surface water, ground water, soils, and stream sediments.

FUNDING: Funding is provided by the National Guard Bureau, Installation Restoration Program. 


\section{Simulation of Ground-Water Flow and the Behavior of Contaminant Plumes in the Alluvial Aquifer, Calvert City}

(KY 91-094)

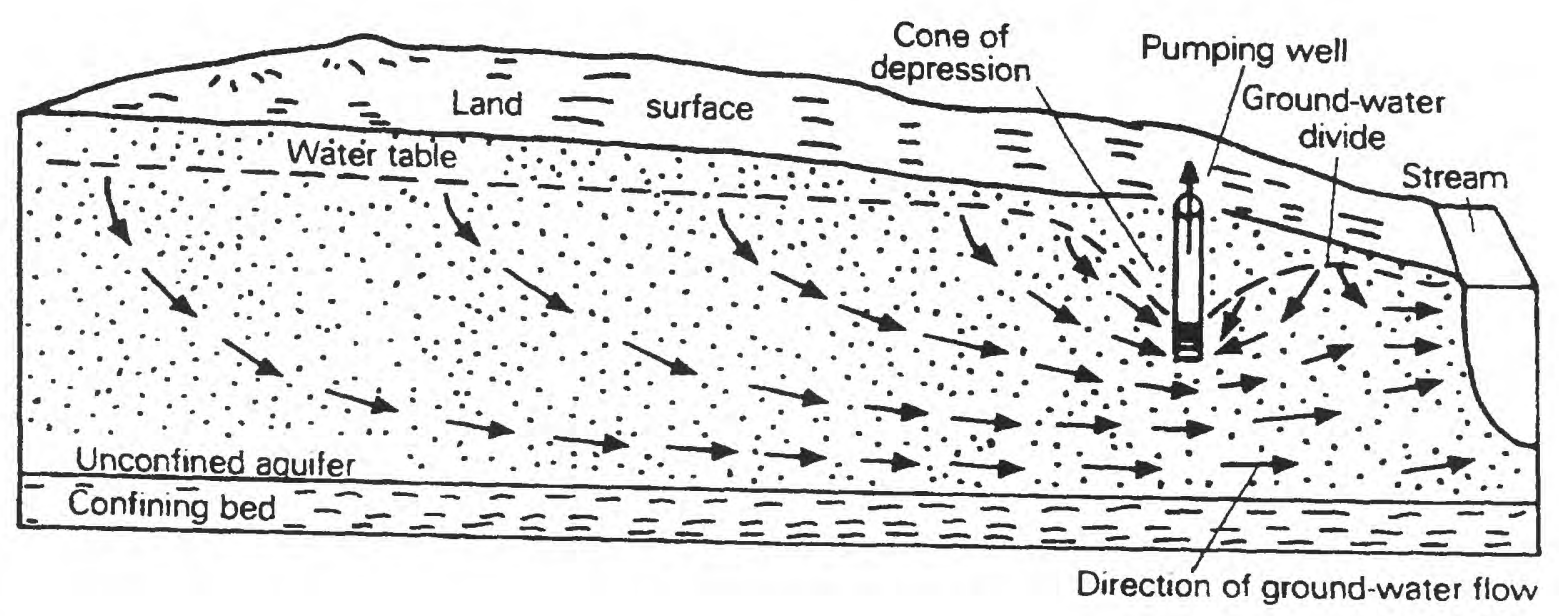

PROBLEM: The behavior of contaminant plumes in complex hydrogeologic settings is often misrepresented in risk assessments, ground-water monitoring networks, and remedial designs. River valley/alluvial aquifer hydraulics reflect the complexity of geologic deposition and unsteady boundary conditions. The study area, located on the southern bank of the Tennessee River, includes a publicsupply wellfield threatened by an industrial complex which includes nine major industries, the two largest generators of hazardous waste in Kentucky, two Superfund sites, and several operative wastedisposal sites. The State, in cooperation with several Federal agencies, is conducting a comprehensive environmental investigation of the Calvert City area.

OBJECTIVES: The goal of the research is to contribute to scientific knowledge of the behavior of contaminant plumes in a river valley/alluvial aquifer hydrogeologic setting. Specific objectives include:

1. Develop a ground-water flow model to be used to identify flow paths and advective travel times.

2. Evaluate aquifer heterogeneity and fluctuating boundary conditions on contaminant transport.

3. Analyze, using the ground-water flow model, the effect of present and projected pumpage configurations, which includes municipal, industrial, and remedial wellfields, on ground-water flow paths and travel times.

FUNDING: Funding is provided by the Federal-State Cooperative Program.

STATE COOPERATOR: Kentucky Department for Environmental Protection 


\section{Empirical Methods for Determining Boundary Stresses at Bridge Piers and Abutments}

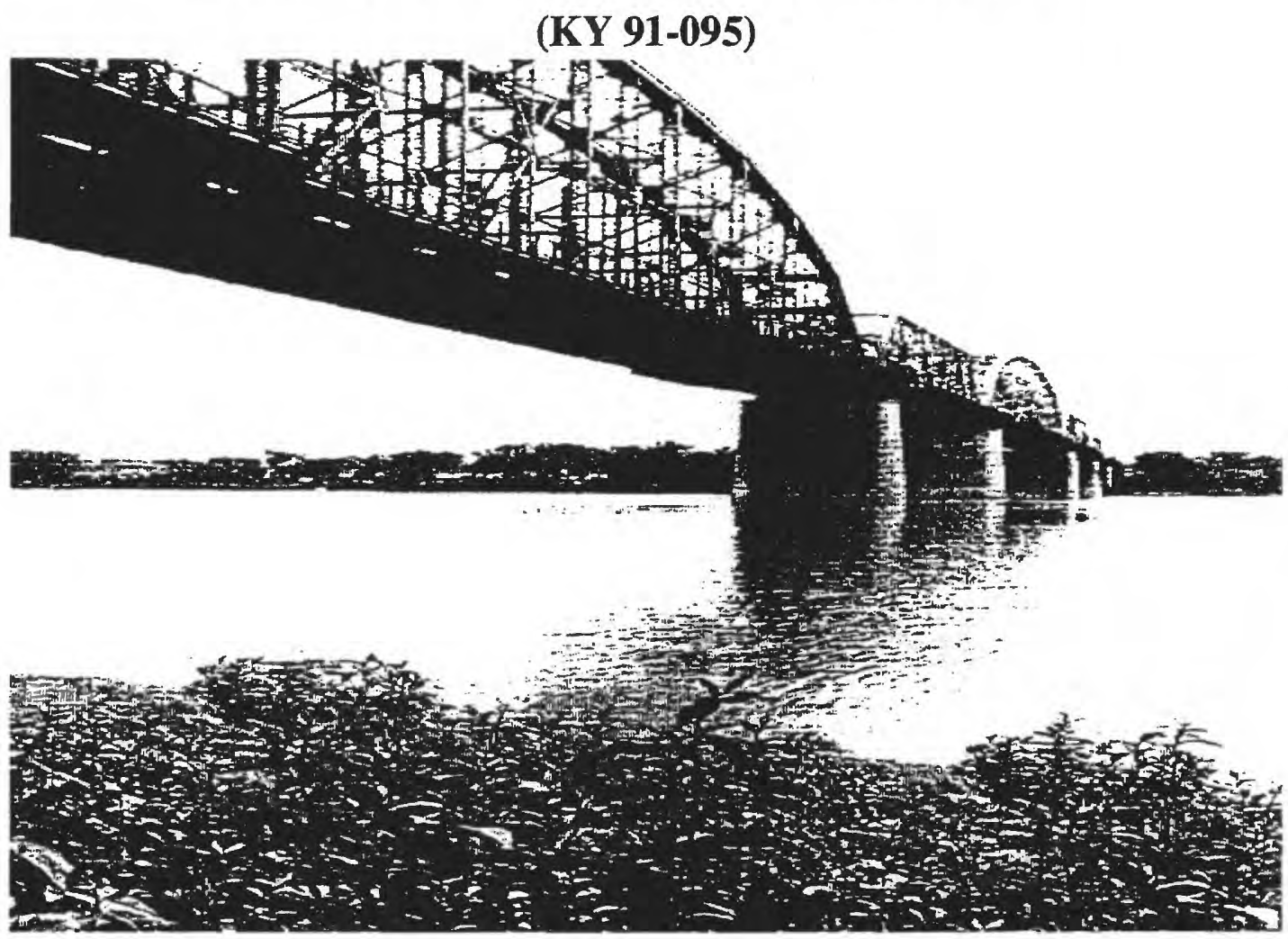

PROBLEM: Researchers have indirectly measured bed stresses under laboratory conditions and have found that bed stresses in the vicinity of model piers and abutments can be 4 to 12 times more than those of the undisturbed flow. The effects of scale on velocities and boundary-shear stresses in the model compared to full-scale prototype conditions are unknown. Therefore, a field investigation of velocities in the vicinity of bridge piers is needed to determine the applicability of model study results to actual field conditions. These data will be used to develop an empirical relation to predict bed stresses in the vicinity of bridge piers and abutments.

OBJECTIVE: Investigate the process of scour mechanisms and riprap stability by determining the applicability of bed-stress measurements, obtained from small-scale model investigations of bridge piers, to bed-stress measurements observed at bridge sites.

FUNDING: Funding is provided by the Federal-State Cooperative Program.

LOCAL COOPERATOR: University of Louisville 


\section{Simulation of Ground-Water Flow, Ohio River Alluvial Aquifer, Owensboro}

(KY 92-096)

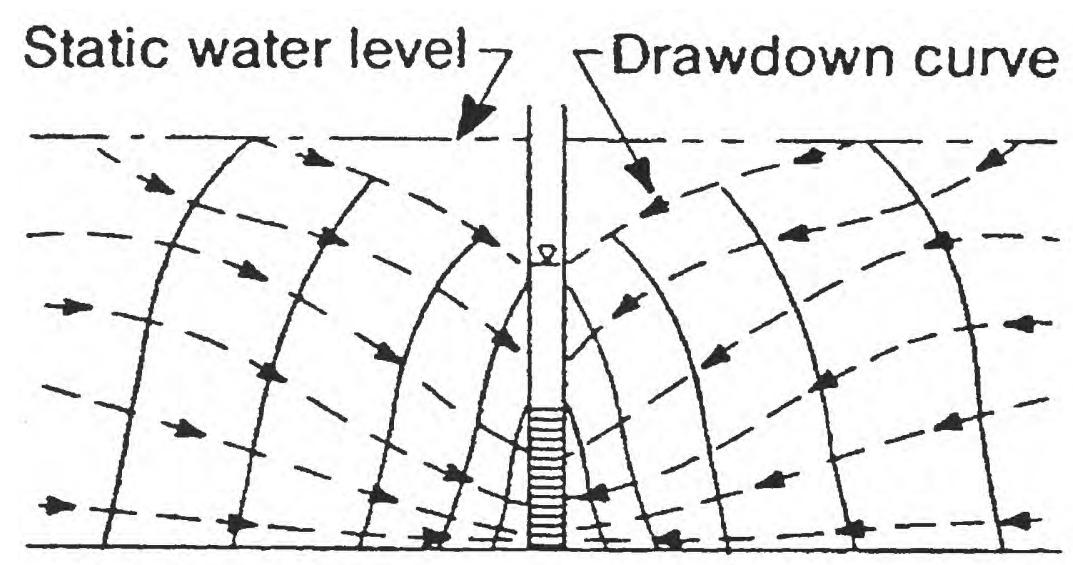

PROBLEM: The Ohio River alluvial aquifer in Owensboro serves as the sole source of drinking water for over 80,000 people in 4 counties. The wellfield consists of approximately 30 wells, making it the largest public ground-water supply in Kentucky. The aquifer is also used directly for industrial water supply and indirectly for waste disposal. Water demand is increasing, and the development of a new wellfield is planned. Most of the ground water extracted for use as public drinking water in Kentucky is developed from similar alluvial aquifers, as are many municipal wellfields across the country. Better tools for the delineation of areas recharging the alluvial aquifer are needed to provide a framework for land- and water-resource management and protection decisions.

\section{OBJECTIVES:}

1. Develop a preliminary ground-water flow model for defining the recharge areas for existing and potential public water-supply wells.

2. Perform a preliminary analysis of model sensitivity to boundary conditions.

3. Identify ground-water flow paths.

4. Demonstrate the use of geographic information system (GIS) technology for land- and waterresource management and protection decisions.

FUNDING: Funding is provided by the Federal-State Cooperative Program.

LOCAL COOPERATOR: City of Owensboro 


\section{Freshwater Mussels -- Relevance of Shell-Layer and Tissue Accumulation Processes for Describing Water-Quality Trends}

(KY 93-099)

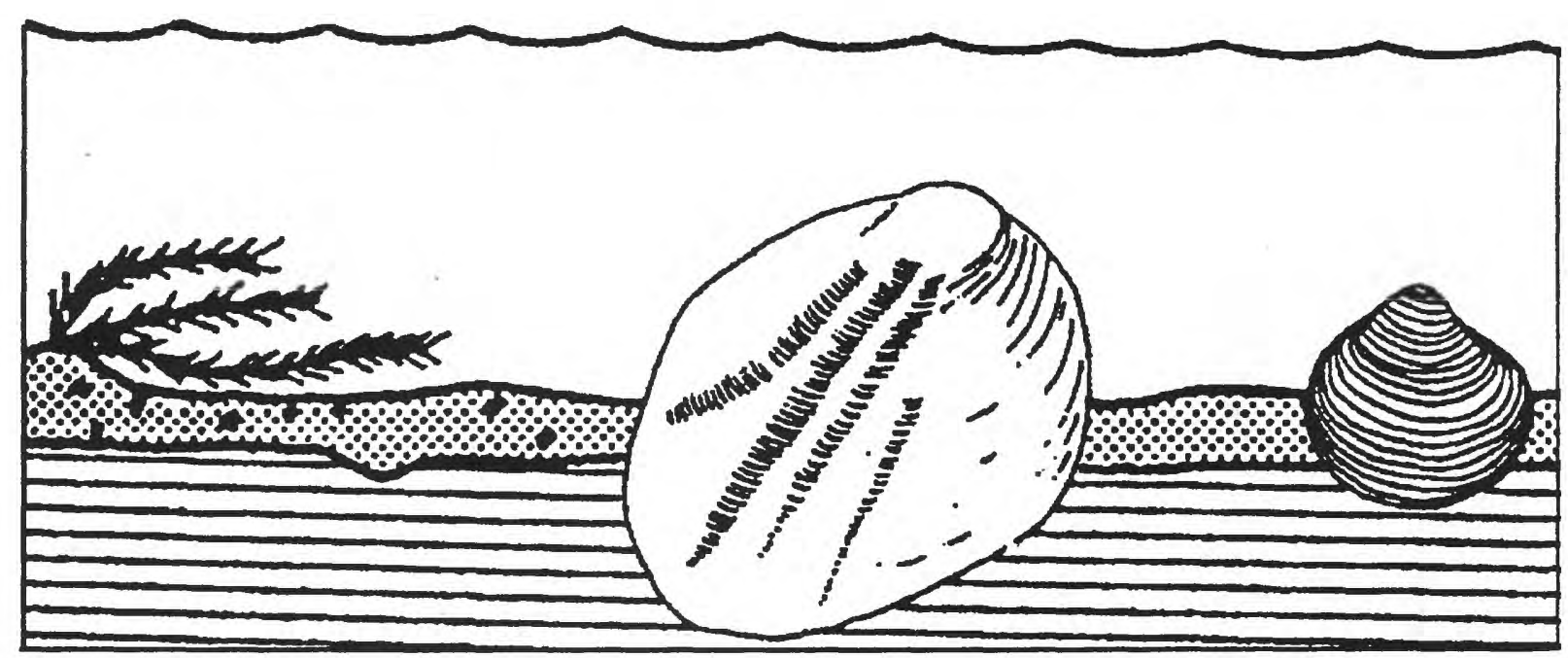

PROBLEM: Detection of water-quality trends for trace metals and pesticides is difficult in many streams because of insufficient data collection and the high frequency of results that are below analytical detection levels. Freshwater mussels accumulate concentrations of trace constituents from water and suspended particulates in their tissues and shells, at levels that may be easily detected with existing laboratory methods. Native mussels frequently live longer than 20 years and accumulate concentrations of trace metals in annual shell layers that may potentially be used to estimate the direction and magnitude of water-quality trends. However, their distribution and total numbers are limited. The Asiatic clam (Corbicula) is present in many mid-order and smaller streams of the central and northeastern regions of the country, and although it typically lives for less than 5 years, it is available in large numbers. Although the environmental effect of trace metals and pesticides has been the subject of considerable attention and concern, much remains unknown about the sources, bioavailability, and bio-magnification potential of these constituents.

\section{OBJECTIES:}

1. Determine which trace metals accumulate in shell layers of freshwater mussels and evaluate whether changes or trends in shell-layer concentrations may be used to assess long-term waterquality trends.

2. Evaluate the bio-availability and bio-magnification of trace metals and pesticides in tissues of Corbicula and native mussels.

3. Derive bioaccumulation factors (BAF's) for these constituents by comparing tissue concentrations with concentrations in water or by the application of rate-constant based toxicokinetic research.

FUNDING: Funding is provided by the Federal-State Cooperative Program.

STATE COOPERATORS: Kentucky Natural Resources and Environmental Protection Cabinet Kentucky Department of Fish and Wildlife Resources

Kentucky State University 


\title{
Investigation of Subsurface Flow and Karst Hydrology of the Lost River Watershed, South-Central Indiana
}

\author{
(KY 94-835)
}

PROBLEM: The Lost River flows across an extensive sinkhole plain developed on karsted Mississippian-age limestones in south-central Indiana. Near Orleans, Indiana, the Lost River is a drybed stream underdrained by solution conduits, and surface flows from the upper portion of the watershed are normally routed underground to a large artesian spring known as the Lost River Rise. Under high-flow conditions, the hydraulic capacity of the subsurface conduits is exceeded and flow retums to the surface stream channel, which functions as a flood-overflow route. When this occurs, rapid filling of the subsurface conduits and surface channel with water inhibits drainage of additional runoff and increases the potential of sinkhole flooding throughout the area. The presence of several large karst springs within the Lost River watershed indicates that the karstic subsurface drainage network is complex. Information is needed about karstic drainage routes within the Lost River watershed to facilitate a reconnaissance study of sinkhole flooding in the community of Orleans, Indiana, being conducted by the U.S. Army Corps of Engineers.

\section{OBJECTIVES:}

1. Conduct qualitative dye-tracing studies to determine ground-water flow paths from sinkholes, sinking streams, and stormwater drainage wells in the vicinity of Orleans, Indiana.

2. Identify the hydrologic boundaries of the subsurface karst drainage basins within the Lost River watershed.

3. Assess hydraulic characteristics of the subsurface conduits and ground-water/surface-water interactions.

FUNDING: Funding is provided by the U.S. Army Corps of Engineers. 


\section{Determination of Catchment Area and Hydrologic Characteristics of Boiling Spring, Fort Campbell Military Base, Kentucky-Tennessee}

(KY 94-840)

PROBLEM: Much of the area of the Fort Campbell Military Base, located along the KentuckyTennessee State line, is underlain by karsted Mississippian-age limestones. The base water supply is obtained from a large karst spring, known as Boiling Spring. Fort Campbell is preparing a water-supply management and Wellhead Protection Plan required by Tennessee State regulations. The size and hydrologic boundaries of the catchment (total recharge area) of Boiling Spring are unknown, as are the hydrologic (flow) characteristics of the spring. Information is needed in order to assess the suitability of the spring to provide a water supply adequate for current and future needs, to evaluate the potential impacts of contaminants on the base, and to develop an effective water-supply management and protection plan.

\section{OBJECTIVES:}

1. Perform qualitative dye-tracing studies to establish point-to-point connections between the watersupply spring and discrete points of recharge (sinkholes and sinking streams) on the base and to delineate the areal extent of the ground-water basin drained by Boiling Spring.

2. Perform quantitative dye-tracing studies of suspected losing surface stream reaches to confirm and quantify loss of flow volume and to determine the fraction of flow from losing stream reaches that provide recharge to the water-supply spring.

3. Perform quantitative dye-tracing studies to assess the hydraulic characteristics of the water-supply spring and to determine time-of-travel and concentration/dispersion factors for potential contaminants moving along specific ground-water flow paths from discrete points of recharge (sinkholes and sinking streams) on the base.

FUNDING: Funding is provided by the U.S. Department of the Army. 


\section{Superfund Technical Assistance Program}

The U.S. Environmental Protection Agency (USEPA) has responsibility for implementing the Superfund Amendments and Reauthorization Act (otherwise known as CERCLA, SARA, or Superfund) in Kentucky. At selected sites, the USEPA has requested technical assistance from the USGS in addressing hydrologic issues.

Under a Memorandum of Agreement between the two Federal agencies, the Kentucky District is currently providing or has provided support during the remedial investigation and remedial action process at:

- Caldwell Lace-Leather Superfund Site, Logan County (KY 90-085)

- Distler Brickyard Superfund Site, Hardin County (KY 92-097)

- Green River Disposal Superfund Site, Daviess County (KY 91-093)

- Howe Valley Landfill Superfund Site, Hardin County (KY 90-083)

- Laurel County-Singleton Landfill Sites, Laurel County (KY 90-082)

- Lexington-Bluegrass Amy Depot, Fayette County (KY 93-098)

- Maxey Flats Low-Level Radioactive Waste Superfund Site, Fleming County (KY 00-002)

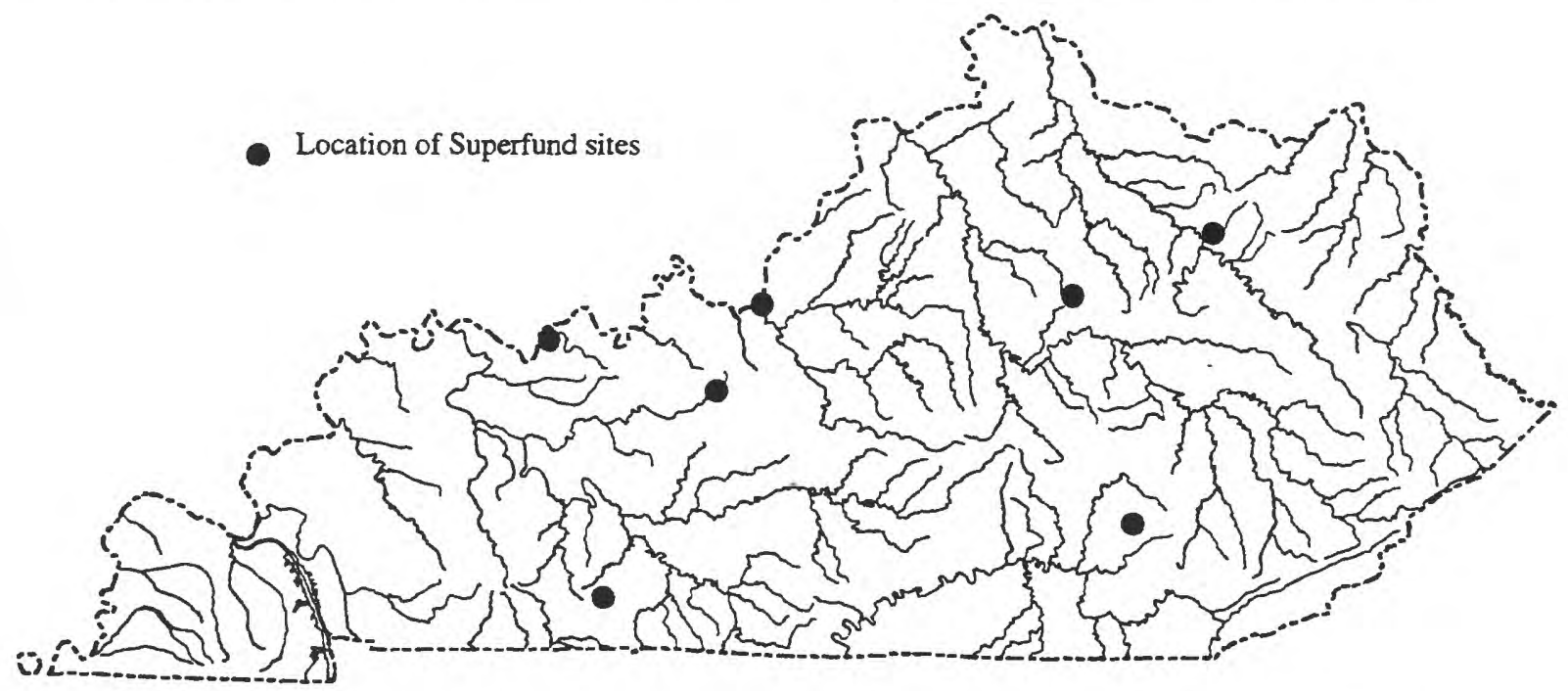

The USGS provides a wide range of technical support to the USEPA. Such support can include, but is not limited to:

- Geologic coring, drilling of monitoring wells, and installation of piezometers

- Soil, ground-water, and surface-water-quality sampling

- Water-level measurements, streamgaging, and surveying

- Design, implementation, and interpretation of aquifer tests

- Interpretation of site data and review of project work plans and technical reports

- Qualitative or quantitative dye-tracer tests to define directional trends or solute-transport characteristics of ground-water flow in karst and fractured-rock terranes

Assistance in the overview of efforts of "principal responsible parties" during site investigation and remediation. 


\title{
SOURCES OF WATER-RESOURCES INFORMATION AND REFERENCES FOR KENTUCKY
}

USGS publications and other selected references on water resources in Kentucky are listed in this section. USGS Water-Resources Investigations (WRI) and Open-File (OF) Reports for Kentucky are generally available free of charge but in limited supplies. These reports are distributed by the District office in Louisville. All USGS publications and maps for Kentucky are available for inspection at the Kentucky District office in Louisville, and many of the reports are available for inspection at public and university libraries. New reports published by the USGS are announced monthly in "New Publications of the Geological Survey." Subscriptions to this monthly list are available free on request to the U.S. Geological Survey, MS 329, 12201 Sunrise Valley Drive, Reston, Virginia 22092.

Questions specific to the water resources of Kentucky can be directed to the Kentucky District office. This office will answer inquiries about data, reports, and other Kentucky water-resources publications.

\author{
Alfred L. Knight, District Chief \\ U.S. Geological Survey, WRD \\ 2301 Bradley Avenue \\ Louisville, KY 40217 \\ (502) $582-5242$
}

The USGS Office of Water Data Coordination (OWDC) is the focal point for interagency coordination of ongoing and planned water-data acquisition activities of all Federal agencies and many non-Federal organizations. The "National Handbook of Recommended Methods for WaterData Acquisition," indexes to the "Catalog of Information on Water Data," and other publications are available from OWDC. For further information, write:

Office of Water Data Coordination
U.S. Geological Survey, MS 417
12201 Sunrise Valley Drive
Reston, VA 22092
(703) 648-5016

The National Water Data Exchange (NAWDEX) maintains a computerized data system that identifies sources of water data and indexes information on the water data available from the sources. The NAWDEX Program Office and local Assistance Centers assist data users in locating sources of water data, identifying sites at which data have been collected, and obtaining specific data. For further information write:

\author{
National Water Data Exchange \\ U.S. Geological Survey, MS 421 \\ 12201 Sunrise Valley Drive \\ Reston, VA 22092 \\ (703) 648-5677
}


The National Water Information System (NWIS) is the water data base of the USGS. It contains data on stream discharge (flow) and stage (height), reservoir and lake storage, ground-water levels, well and spring discharge, and the quality of surface and ground water. For information about types and acquisition of data, contact the District Chief for Kentucky.

Earth Science Information Centers (ESIC's) offer nationwide information and sales service for USGS map products and earth science publications. This network of USGS ESIC's provides information about geologic, hydrologic, topographic, and land use maps, books, and reports. For further information contact one of the following or call 1-800-USA-MAPS:

\author{
Earth Science Information Center \\ U.S. Geological Survey \\ 507 National Center \\ Reston, VA 22092 \\ Telephone: (703) 648-6045 \\ TDD: (703) 648-4101*
}

\author{
Earth Science Information Center \\ U.S. Department of Interior \\ 1849 C Street, NW, Room 2650 \\ Washington, DC 20240 \\ Telephone: (202) 208-4047 \\ TDD: (202) 219-1510*
}

*TDD-Telecommunications Device for the Deaf

Since 1879, the USGS has served the public and Federal, State, and local governments by collecting, analyzing, and publishing detailed information about the Nation's mineral, land, and water resources. This information is in a variety of map, book, and other formats and is available from several sources within the USGS. To order USGS book publications, catalogs, and pamphlets, or for information on the availability of microfiche or paper duplicate copies of WRI and OF Reports, write:

\author{
U.S. Geological Survey \\ Earth Science Information Center \\ Open-File Reports Section \\ Box 25286, MS 517 \\ Denver Federal Center \\ Denver, CO 80225
}

To order maps, write:

\author{
U.S. Geological Survey \\ Map Distribution \\ Box 25286, Building 810 \\ Denver Federal Center \\ Denver, CO 80225
}

Several reports may also be purchased as hard copy or microfiche from the National Technical Information Service (NTIS), U.S. Department of Commerce, Springfield, VA 22161. 
The following is a listing of references on the water resources of Kentucky by type of publication:

\section{PROFESSIONAL PAPERS}

427-A Description of physical environment and of strip-mining operations in parts of Beaver Creek basin, Kentucky, by J.J. Musser, 1963.

427-B Influences of strip mining on the hydrologic environment of parts of Beaver Creek basin, Kentucky, 1955-59, by C.R. Collier and others, 1964.

427-C Influences of strip mining on the hydrologic environment of parts of Beaver Creek basin, Kentucky, 1955-66, by C.R. Collier, R.J. Pickering, and J.J. Musser, 1970.

427-D Influences of strip mining on the hydrologic environment of parts of Beaver Creek basin, Kentucky, 1973-74 by R.A. Krieger, 1985.

448-A Availability of water in the Mississippi Embayment, by E.M. Cushing and others, 1970.

448-C Cretaceous aquifers in the Mississippi Embayment, by E.H. Boswell and others, 1965.

448-D Tertiary aquifers in the Mississippi Embayment, by R.L. Hosman and others, 1968.

448-E Quaternary aquifers in the Mississippi Embayment, by E.H. Boswell, E.M. Cushing. and R.L. Hosman, 1968.

448-H Low-flow characteristics of streams in the Mississippi Embayment in Tennessee, Kentucky, and Illinois, by P.R. Speer and others, with section on quality of water, by H.G. Jeffrey, 1965.

813-A Summary appraisal of the Nation's ground-water resources--Ohio Region, by R.N. Bloyd, Jr., 1974.

1098 Flood of April 1977, in the Appalachian region of Kentucky, Tennessee, Virginia, and West Virginia, by G.S. Runner, U.S. Geological Survey, and E.H. Chin, National Weather Service, National Oceanic and Atmospheric Administration, 1980.

\section{WATER-SUPPLY PAPERS}

134 Underground waters of Tennessee and Kentucky west of the Tennessee River and adjacent area in Ilinois, by L.C. Glenn, 1906.

233 Water resources of the Blue Grass Region, Kentucky, by G.C. Matson, 1909.

334 The Ohio Valley flood of March-April 1913, by A.H. Horton and H.J. Jackson, 1913.

800 The floods of March 1936--Part 3, Potomac, James, and Upper Ohio Rivers, 1937.

838 Floods of Ohio and Mississippi Rivers, January-March 1937, by C.M. Grover, with a section on flood deposits of the Ohio River, January-February 1937, by

G.R. Mansfield, 1938. 


\section{WATER-SUPPLY PAPERS--continued}

967-B Notable local floods of 1939--Part 2, Flood of July 5, 1939, in eastern Kentucky, by F.F. Schrader, 1945.

1192 Water levels and artesian pressures in observation wells in the United States in 1951, Part 2, Southeastern States, section on Kentucky, p. 114-145, 1954.

1257 Geology and ground-water resources of the Paintsville area. Kentucky, by J.A. Baker, 1955.

1299 The industrial utility of public water supplies in the United States, 1952, part 1, States east of the Mississippi River, by E.W. Lohr and S.K. Love, 1954.

1305 Compilation of records of surface waters of the United States through September 1950, Part 3-A, Ohio River Basin except Cumberland and Tennessee River Basins, 1957.

1328 Ground-water resources of the Hopkinsville quadrangle, Kentucky, by E.H. Walker, 1956.

1356 Geology and ground-water resources of the Henderson area, Kentucky, by E.J. Harvey, 1956.

1359 Geology and ground-water resources of the Prestonsburg quadrangle. Kentucky, by W.E. Price, Jr., 1956.

1360-B Ground water in northeastern Louisville, Kentucky, by M.I. Rorabaugh, 1956.

1411 The deep channel and alluvial deposits of the Ohio Valley in Kentucky, by E.H. Walker, 1957.

1417 Geology and ground-water resources of the Paducah area, Kentucky, by H.L. Pree, Jr., W.H. Walker, and L.M. MacCary, 1957.

1475-Q Present and future water supply for Mammoth Cave National Park, Kentucky, by R.V. Cushman, R.A. Krieger, and J.A. McCabe, 1965.

1528 Geology and ground-water resources of the Scottsville area, Kentucky, by W.B. Hopkins, 1963.

1533 Reconnaissance of ground-water resources in the Blue Grass region, Kentucky, by W.N. Palmquist, Jr., and F.R. Hall, 1961.

1579 Progress report on the ground-water resources of the Louisville area. Kentucky, 1949-55, by E.A. Bell, R.W. Kellogg, and W.K. Kulp, 1963.

1599 Reconnaissance of ground-water resources in the Western Coal Field region, Kentucky, by B.W. Maxwell and R.W. Devaul, 1962.

1603 Reconnaissance of ground-water resources in the Mississippian Plateau region, Kentucky, by R.F. Brown and T.W. Lambert, 1963.

1607 Reconnaissance of ground-water resources in the Eastem Coal Field region, Kentucky, by W.E. Price, Jr., D.S. Mull, and C. Kilburn, 1962. 


\section{WATER-SUPPLY PAPERS--continued}

1652-A Floods of January-February 1957 in southeastem Kentucky and adjacent areas, 1964.

1700 Geochemistry of natural waters of the Blue Grass region, Kentucky, by G.E. Hendrickson and R.A. Krieger, 1964.

1798-G Sedimentation in Plum Creek Subwatershed No. 4, Shelby County, north-central Kentucky, by P.W. Anttila, 1970.

1809-A Ground-water resources of the Jenkins-Whitesburg area, Kentucky, by D.S. Mull. 1965.

1812 Public water supplies of the 100 largest cities in the United States, 1962, by C.N. Durfor and E. Becker, 1964.

1818 Hydrology of the alluvial deposits in the Ohio River valley in Kentucky, by J.T. Gallaher and W.E. Price, Jr., 1966.

1819-C Summary of hydrologic conditions of the Louisville area, Kentucky, by E.A. Bell, 1965.

1837 Hydrology of the cavernous limestones of the Mammoth Cave area, Kentucky, by R.F. Brown, 1966.

1840-A Floods of March 1964 along the Ohio River, by H.C. Beaber and J.O. Rostvedt, 1965.

1867 Occurrence of fresh water in the Lee Formation in parts of Elliott. Johnson. Lawrence, Magoffin, and Morgan Counties, Eastern Coal Field region, Kentucky, by H.T. Hopkins, 1970.

1940 Effects of coal mining on the water resources of the Tradewater River basin, Kentucky, by H.F. Grubb and P.D. Ryder, 1972.

1987 Subsurface geology and ground-water resources of the Jackson Purchase region. Kentucky, by R.W. Davis, T.W. Lambert, and A.J. Hansen, Jr., 1973.

2177 Hydrologic effects of stress-relief fracturing in an Appalachian valley, by G.G. Wyrick and J.W. Brochers, 1981.

2202 Chloroform contamination in part of the alluvial aquifer, southwest Louisville, Kentucky, R.W. Davis and E.W. Matthews, 1983.

2250 National Water Summary 1983-Hydrologic events and issues, 1984 (State summary for Kentucky, p. 132-134).

2275 National Water Summary 1984-Hydrologic events, selected water-quality trends, and ground-water resources, 1985 (State summary for Kentucky, p. 223-228).

2300 National Water Summary 1985-Hydrologic events and surface-water resources, 1986 (State summary for Kentucky, p. 245-250). 


\section{WATER-SUPPLY PAPERS--continued}

2325 National Water Summary 1986-Hydrologic events and ground-water quality, 1988 (State summary for Kentucky, p. 265-272; and Drought in the Southeastern United States, 1985-86, by H.G. Golden and H.F. Lins, p. 35-41).

2350 National Water Summary 1987-Hydrologic events and water supply and use, 1990 (State summary for Kentucky, p. 267-274).

2375 National Water Summary 1988-89-Hydrologic events and floods and droughts, 1991 (State summary for Kentucky, p. 295-302).

\section{CIRCULARS}

240 Geology and ground-water resources of the Covington-Newport alluvial area, Kentucky, by E.H. Walker, 1953.

276 Water resources of the Louisville area, Kentucky and Indiana, by M.I. Rorabaugh, F.F. Schrader, and L.B. Laird, 1953.

287 Public and industrial water supplies of the Jackson Purchase region, Kentucky, by H.L. Pree, Jr., and W.H. Walker, 1953.

299 Public and industrial water supplies of the Blue Grass region, Kentucky, by W.N. Palmquist, Jr., and F.R. Hall, 1954.

339 Public and industrial water supplies of the Western Coal Field region, Kentucky, by B.W. Maxwell, 1954.

341 Public and industrial water supplies of the Mississippian Plateau region, Kentucky, by R.F. Brown, 1954.

369 Public and industrial water supplies of the Eastern Coal Field region, by J.A. Baker and W.E. Price, Jr., 1956.

439 Time of travel of water in the Ohio River, Pittsburgh to Cincinnati, by R.E. Steacy, 1961.

471 Water resources and the Mississippi Embayment project, by E.M. Cushing, 1963.

526 Stream quality in Appalachia as related to coal-mine drainage, 1965, by J.E. Biesecker and J.R. George, 1966.

900 Guide to Obtaining USGS Information, by K. Dodd, H.K. Fuller, and P.F. Clarke, 1989.

1010. Goals of the U.S. Geological Survey, 1986. 


\section{FACT SHEETS}

Advantages and limitations of water-supply alternatives, by R.J. Veley, 1992 (Open-File Report 92-119).

Distributed Information System, by A.W. Harbaugh, 1986 (Open-File Report 85-649).

Federal-State Cooperative Water Resources Program, April 1984.

Hazardous-waste hydrology, November 1983.

History of water resources activities of the U.S. Geological Survey, by S.L. Holmes, 1985 (Open-File Report 85-646).

Hydrologic data collection via satellite, April 1984.

Hydrologic hazards in karst terrane, by N.C. Crawford, 1985 (Open-File Report 85-677).

National water-information clearinghouse activities: Ground-water perspective, by C.A. Haupt and R.A. Jensen, 1988 (Open-File Report 88-114).

National Water-Quality Assessment: Ground-Water Pilot Program, by W.W. Alley and W.G. Wilber, 1988 (Open-File Report 88-175).

National Water-Quality Assessment Pilot Program, by W.G. Wilber and W.W. Alley, 1988 (Open-File Report 88-312).

National Water Summary Program, January 1984.

The National Water-Use Information Program, November 1983.

Regional Aquifer-System Analysis (RASA) Program, by R.J. Sun, 1988 (Open-File Report 88-118).

Regional aquifer systems of the United States, April 1984.

Toxic waste -- Ground-water contamination, November 1983.

U.S. Geological Survey ground-water studies in Kentucky, by R.J. Faust and L.H. Woosley, Jr., 1988 (Open-File Report 88-124).

Water-Data Program, April 1984.

\section{WATER-RESOURCES INVESTIGATIONS REPORTS}

WRI/NTIS Simulated drawdown for selected well fields in the Ohio River alluvial aquifer, 2-74 by H.F. Grubb, 1975 (PB-239 163/AS).

WRI/OF Ground water in the alluvium along the Cumberland River between Smithland, 4-75 Kentucky, and Barkley Dam, by P.D. Ryder, 1975.

WRI/OF Ground water in the alluvium along the Green River between its mouth and 53-73 Woodbury, Kentucky, by P.D. Ryder, 1974. 


\section{WATER-RESOURCES INVESTIGATIONS REPORTS--continued}

WRI

$76-43$

Hydrology of the Princeton area, Kentucky, by R.O. Plebuch, 1976.

WRI/NTIS Technique for estimating magnitude and frequency of floods in Kentucky,

76-62 by C.H. Hannum, 1976 (PB 263 762/AS).

WRI

76-86

WRI Ground-water resources of the Lexington, Kentucky, area, by R.J. Faust, 1977.

76-113

WRI

$77-24$

Theoretical drawdown due to simulated pumpage from the Ohio River alluvial

WRINTIS Rising ground-water level in downtown Louisville, Kentucky, 1972-77, by

77-92

J.M. Kernodle and D.V. Whitesides, 1977 (PB 273 067/AS).

WRI/NTIS Fluvial sediment of Fishtrap and Dewey Lakes drainage basins, Kentucky-Virginia,

$77-123$

by W.F. Curtis, R.F. Flint, and F.H. George, with a section on water quality by J.F. Santos, 1978 (ADA-056 573).

WRI/OF Potentiometric surface of the Mississippian aquifer in parts of Trigg, Lyon.

78-25 Caldwell, and Christian Counties, Mississippian Plateau region, Kentucky, by

R.O. Plebuch, 1978.

WRI/OF Selected chemical quality characteristics in streams of Kentucky, 1970-75,

79-21 by J.F. Santos, 1980.

WRI/OF Water in the Elizabethtown area --A study of limestone terrane in north-central

79-53 Kentucky, by T.W. Lambert, 1979.

WRI/OF Derivation of homogenous streamflow records for the Green River basin,

79-1066 Kentucky, by T.W. Hale, 1979.

WRI/OF Ground-water resources in the Cumberland River Basin, Kentucky-Tennessee, by 80-202 D.R. Rima and D.S. Mull, 1980.

WRI/OF Interim report on the investigation of flooding in the Tug Fork basin of Kentucky, 80-1188 Virginia, and West Virginia, by A.G. Scott, 1980.

WRI/OF Hydrology of Area 14, Eastern Coal Province, Kentucky, by F. Quinones and 81-137 others, 1981.

WRI Effects on water quality of coal mining in the basin of the North Fork Kentucky

81-215 River, Eastem Kentucky, by K.L. Dyer, 1983.

WRI/OF Hydrology of Area 33, Eastem Region, Interior Coal Province, Indiana and 81-423 Kentucky, by D.J. Wangsness and others, 1981.

WRI Availability and quality of water from underground coal mines in Johnson and

81-690 Martin Counties, Kentucky, by D.S. Mull, S. Cordivola, and D.W. Risser, 1981. 


\section{WATER-RESOURCES INVESTIGATIONS REPORTS--continued}

WRI/OF Hydrology of Area 15, Eastern Coal Province, Kentucky and Tennessee,

81-809 by D.W. Leist and others, 1982.

WRI/OF Hydrology of Area 17, Eastern Coal Province, Tennessee and Kentucky, by

81-1118 M. Gaydos and others, 1982.

WRI/OF Hydrology of Area 13, Eastern Coal Province, Kentucky, Virginia. and West

82-505 Virginia, by J.L. Kiesler, Jr. and others, 1983.

WRI/OF Hydrology of Area 34, Eastem Region, Interior Coal Province, Kentucky, Indiana, $82-638$

WRI

$83-4014$ and Ilinois, by F. Quinones, K.L. York, and R.O. Plebuch, 1983.

WRI

$83-4152$

A flood model for the Tug Fork basin, Kentucky, Virginia, and West Virginia. by W.H. Doyle, Jr., and others, 1983.

WRI

$83-4233$

Fluvial sedimentation of Kentucky, by R.F. Flint, 1983.

WRI

$83-4240$

Problems of rising ground-water levels in urban areas with special reference to the Louisville, Kentucky area, by D.V. Whitesides, R.J. Faust, and D.D. Zettwoch, 1983.

WRI

84-233

Evaluation of ground-water quality data from Kentucky, by C.L. Sprinkle, R.W. Davis, and D.S. Mull, 1983.

WRI Ground-water hydrology of the Elizabethtown area, Kentucky, by D.S. Mull and 84-4057 M.A. Lyverse, 1984.

WRI Leaching study of oil shale in Kentucky with a section on hydrologic

84-4073 reconnaissance of the oil shale outcrop in Kentucky, by S.S. Leung and others, 1984.

WRI Review of buried crystalline rocks of eastem United States in selected

84-4091 hydrogeologic environments potentially suitable for isolating high-level radioactive wastes, by R.W. Davis, 1984.

WRI Potentiometric surface and water quality in the principal aquifer, Mississippian

84-4102 Plateaus region, Kentucky, by R.O. Plebuch, R.J. Faust, and M.A. Townsend, 1985.

WRI Analysis of characteristics of simulated flows from small surface-mined and

84-4151 undisturbed Appalachian watersheds in the Tug Fork basin in Kentucky, Virginia, and West Virginia, by A.G. Scott, 1984.

WRI Planning report for the Gulf Coast regional aquifer-system analysis in the Gulf of 84-4219 Mexico Coastal Plain, United States, by H.F. Grubb, 1984.

WRI

84-4316

A preliminary evaluation of the precipitation-runoff modeling system, Beaver Creek basin, Kentucky, by D.E. Bower, 1985. 


\section{WATER-RESOURCES INVESTIGATIONS REPORTS--continued}

WRI Calibration and verification of a streamflow simulation model for the Kentucky

85-4052 Green River near Lexington and Frankfort, Kentucky, by C.J. Sholar, 1986.

WRI

$85-4208$

WRI

86-4171

WRI

86-4186

WRI

86-4364

WRI

$87-4000$

WRI

$87-4084$

WRI

$87-4174$

WRI

87-4179

WRI

87-4197

WRI

87-4209

WRI

88-4043

WRI

88-4082

WRI

88-4098

WRI

88-4166

An evaluation of water-quality data from Hydrologic Accounting Unit 051100. Green River basin, Kentucky, by D.W. Leist, 1986.

Water supplies in westem Kentucky during 1984, by C.J. Sholar and P. Wood, 1986.

Processing water chemistry data, Gulf Coast aquifer system, south-central United States, with a summary of dissolved-solids concentrations and water types, by R.A. Pettijohn. 1986.

Definition of the geohydrologic framework and preliminary simulation of groundwater flow in the Mississippi embayment aquifer system, south-central United States, by J.K. Arthur and R.E. Taylor, 1990.

Hydrogeology and preliminary assessment of regional flow in the Upper Cretaceous and adjacent aquifers in the northern Mississippi embayment, by J.V. Brahana and T.O. Mesko, 1988.

Movement of ground water in coal-bearing rocks near Fishtrap Lake in Pike County. Kentucky, by R.W. Davis, 1987.

Dye-tracing techniques used to determine ground-water flow in a carbonate aquifer near Elizabethtown, Kentucky, by D.S. Mull, J.L. Smoot, and T.D. Liebermann, 1988.

Mean velocity, longitudinal dispersion, and reaeration characteristics of selected streams in the Kentucky River basin, by K.J. Ruhl and J.L. Smoot, 1987.

Ground-water levels in the alluvial aquifer at Louisville, Kentucky, 1982-87, by R.J. Faust and M.A. Lyverse, 1987.

Regionalization of peak discharges for streams in Kentucky, by A.F. Choquette, 1988.

Water use in Kentucky, 1985, by C.J. Sholar and V.D. Lee, 1988.

Distribution of dissolved-solids concentrations and temperature in ground water of the Gulf Coast aquifer systems, south-central United States, by R.A. Pettijohn and others, 1988.

Preliminary hydrogeologic evaluation of the Cincinnati Arch region for underground high-level radioactive waste disposal, Indiana, Kentucky, and Ohio, by O.B. Lloyd, Jr., and R.W. Davis, 1989.

Assessment of ground-water contamination in the alluvial aquifer near West Point, Kentucky, by M.A. Lyverse and M.D. Unthank, 1988. 


\section{WATER-RESOURCES INVESTIGATIONS REPORTS--continued}

WRI Cost-effectiveness of the stream-gaging program in Kentucky, by K.J. Ruhl, 1989.

WRI

Ground-water flow in the Gulf Coast aquifer systems, south-central United States--

WRI A preliminary analysis, by A.K. Williamson and others, 1990.

WRI Geohydrology and ground-water quality at selected sites in Meade County,

WRI Kentucky, 1987-88, by D.S. Mull, A.G. Alexander, and P.E. Schultz, 1989.

WRI Ground-water levels in the alluvial aquifer at Louisville, Kentucky, 1987-88.

WRI by R.J. Faust and B.E. Lyons, 1989.

WRI

Ground-water pumpage from the Gulf Coast aquifer system. 1960-85, south-central

WRI United States, by T.O. Mesko and others, 1990.

Hillslope erosion at the Maxey Flats radioactive waste disposal site, northeastern Kentucky, by W.P. Carey, M.A. Lyverse, and C.R. Hupp, 1990.

Summary of biological investigations relating to surface-water quality in the Kentucky River basin, Kentucky, by A.D. Bradfield and S.D. Porter, 1990.

Estimates of hydraulic conductivity from aquifer-test analyses and specific capacity data, Gulf Coast aquifer systems, south-central United States, by D.E. Prudic, 1991.

Water availability and vulnerability of ground water to contamination in

90-4133 northwestern Hardin County, Kentucky, by D.S. Mull, R.J. Faust, and G.R. Martin. 1990.

WRI Gulf Coast Regional Aquifer-System analysis--A Kentucky perspective, by

90-4138 H.F. Grubb and J.K. Arthur, 1991.

WRI Ground-water levels and tritium concentrations at the Maxey Flats low-level

90-4189 radioactive waste disposal site near Morehead, Kentucky, June 1984 to April 1989, K.S. Wilson and B.E. Lyons, 1991.

WRI Effects of oil production on water resources in the Kentucky River basin, Kentucky, 90-4191 by R.D. Evaldi and J.A. Kipp, 1991.

WRI Quality of the Ohio River and atmospheric deposition and its relation to corrosion of 91-4050 lock and dam facilities in the lower Ohio River basin near Paducah, Kentucky, by K.D. White, 1991.

WRI Low-flow characteristics of Kentucky streams, by K.J. Ruhl and G.R. Martin, 1991.

WRI Evaluation of the drought susceptibility of water supplies used in the Kentucky 91-4105 River basin in 1988, by C.J. Sholar and P.A. Wood, 1991.

WRI Water-use data collection techniques in the southeastern United States, Puerto Rico, 92-4028 and the U.S. Virgin Islands, by T.W. Holland, 1992. 


\section{WATER-RESOURCES INVESTIGATIONS REPORTS--continued}

WRI

$92-4057$

WRI

92-4078

WRI

$92-4138$

WRI

$92-4150$

WRI

$92-4173$

WRI

$92-4195$

WRI

93-4005

Trihalomethane formation potential of Kentacky River water, by R.E. Rathbun, 1993.

Quality of storm-water runoff in three watersheds in Elizabethtown. Kentucky, by R. Garcia, 1992.

Contamination of soil, soil gas, and ground water by hydrocarbon compounds near Greear, Morgan County, Kentucky, by A.G. Alexander, D.D. Zettwoch, M.D. Unthank, and R.B. Burns, 1992.

Water quality of selected streams in Jefferson County, Kentucky, 1988-91, by R.D. Evaldi, R.J. Burns, and B.L. Moore, 1993.

Regionalization of harmonic-mean streamflows in Kentucky, by G.R. Martin and K.J. Ruhl, 1993.

Use of dye tracing to define the direction of ground-water flow from a Superfund waste-disposal site in karst terrane, near Auburn, Kentucky, by D.S. Mull, 1993.

Geohydrology and quality of shallow ground water at and near the Old Laurel County and G.C. Singleton Landfills, Laurel County, Kentucky, by J.M. Pamell, 1993.

\section{OPEN-FILE REPORTS}

78-14 Flood of April 1977, Kentucky, Tennessee, Virginia, and West Virginia, by G.S. Runner, 1977.

78-129 Water levels in observation wells in Kentucky, 1935 through 1976, by D.V. Whitesides, J.M. Kemodle, and D.W. Leist, 1978.

78-200 Quality of Rivers of the United States, 1975 Water Year--based on the National Stream Quality Accounting Network (NASQAN), by J.C. Briggs and J.F. Ficke, 1977.

79-746 Drainage areas of the Twelvepole Creek basin, West Virginia; Big Sandy River basin, West Virginia; Tug Fork basin, Virginia, Kentucky, and West Virginia, by M.W. Wilson, 1979.

79-977 Floods of December 1978 in Kentucky, by J.N. Sullavan, F. Quinones, and R.F. Flint, 1979.

79-1329 Preliminary hydrogeologic investigation of the Maxey Flats radioactive waste burial site, Fleming County, Kentucky, by H.H. Zehner, 1979.

80-594 Quality of rivers in the United States, 1976 Water Year--based on the National Stream Quality Accounting Network (NASQAN), by L.J. Britton and others, 1983.

80-685 A compilation of ground water quality data for Kentucky, by R.J. Faust, G.R. Banfield, and G.A. Willinger, 1980. 


\section{OPEN-FILE REPORTS--continued}

80-1221 Flow duration at selected stream sites in Kentucky, by F. Quinones, J. Kiesler, and J. Macy, 1980.

80-1225 Low-flow characteristics of Kentucky Streams, 1980, by J.N. Sullavan, 1980.

81-61 Drainage areas of streams at selected locations in Kentucky, by D.E. Bower and W.H. Jackson, 1981.

82-640 Hydrology of the Somerset area, Kentucky, by R.W. Davis.

82-641 Water Supplies for the London-Corbin area, Kentucky, by R.W. Davis.

83-133 Hydrogeologic investigation of the Maxey Flats radioactive waste burial site, Fleming County, Kentucky, by H.H. Zehner, 1983.

84-704 Streamflow and basin characteristics at selected sites in Kentucky, by N.B. Melcher and K.J. Ruhl, 1984.

84-705 Low-flow characteristics of Kentucky streams, 1984, by J.N. Sullavan, 1984.

85-683 Ground-water quality data from the northem Mississippi embayment--Arkansas, Missouri, Kentucky, Tennessee, and Mississippi, by J.V. Brahana and others, 1985.

86-71 Water resources activities in Kentucky, 1986, compiled by R.J. Faust, 1986.

86-535 Data from test drilling to trace movement of ground water in coal-bearing rocks near Fishtrap Lake in Pike County, Kentucky, by R.W. Davis, 1986.

87-214 Record of wells and chemical analysis of water from wells for the period June 13, 1984, to December 4, 1986, at the Maxey Flats radioactive waste disposal site, Kentucky, by M.A. Lyverse, 1987.

87-234 Surface water quality assessment of the Kentucky River basin, Kentucky: Project description, by K.D. White and others, 1987.

87-249 Construction, geologic, and hydrologic data for observation wells in the Reelfoot Lake area, Tennessee and Kentucky, by W.M. Bradley, 1987.

87-677 Geophysical well-log data base for the Gulf Coast Regional Aquifer Systems, southcentral United States, by T.A. Wilson and R.L. Hosman, 1987.

87-727 Kentucky ground-water quality, by J.L. Kiesler, L.H. Woosley, Jr., and R.W. Davis, 1987. Kentucky section of 1986 National Water Summary.

88-316 Geohydrologic units of the Mississippian embayment and Texas coastal uplands aquifer systems, south-central United States, by R.L. Hosman and J.S. Weiss, 1988.

88-497 History of suspended-sediment data collection and inventory of available data for the Tennessee and Cumberland River basins, by W.P. Carey and others, 1988. 


\section{OPEN-FILE REPORTS--continued}

89-50 Programs and activities of the Kentucky District, Water Resources Division, U.S. Geological Survey, by L.H. Woosley, Jr., and R.J. Faust, 1989.

89-582 Streamflow, specific-conductance, and temperature data for Bayou and Little Bayou Creeks near Paducah, Kentucky, August 15 and 16, 1989, by R.D. Evaldi and D.L. McClain, 1989.

90-158 Flood of February 1989 in Kentucky, by D.L. McClain, 1990.

90-360 Surface water-quality assessment of the Kentucky River basin, Kentucky: Analysis of available water-quality data through 1986, by J.L. Smoot, T.D. Liebermann, R.D. Evaldi, and K.D. White, 1991.

92-638 Stormwater data for Jefferson County, Kentucky, 1991-92, by R.D. Evaldi and B.L. Moore, 1992.

\section{UNNUMBERED OPEN-FIL REPORTS}

Barnes, H.H., Jr., 1964, Floods of March 1963, Alabama to West Virginia.

Beaber, H.C., 1970, A proposed streamflow data program for Kentucky.

Faust, R.W., 1984, Programs and activities of the Kentucky District, Water Resources Division, U.S. Geological Survey.

Faust, R.W., 1982, Programs and activities of the Kentucky District, Water Resources Division, U.S. Geological Survey.

Faust, R.W., 1980, Programs and activities of the Kentucky District, Water Resources Division, U.S. Geological Survey.

Faust, R.W., 1977, Programs and activities of the Kentucky District, Water Resources Division, U.S. Geological Survey.

Hannum, C.H., 1963, Floods of July 29 and 30, 1961, in Eastern Kentucky.

Hopkins, H.T., 1966, Water resources of the Fayette County area, Kentucky.

Kreiger, R.A., 1961, Chemical quality conditions of the Green River at Munfordville, Kentucky, October 1956 - September 1960.

McCabe, J.A., 1958, Floods in Kentucky, magnitude and frequency.

Otton, E.G., 1948, Geology and ground-water resources of the London area, Kentucky.

Otton, E.G., 1948, Ground-water resources of the Elizabethtown area, Kentucky.

Otton, E.G., 1948, Ground-water supplies of the Campbellsville area, Kentucky.

Rorabaugh, M.I., 1946, Ground-water resources of the southwestem part of the Louisville area, Kentucky. 


\section{UNNUMBERED OPEN-FILE REPORTS--continued}

Rorabaugh, M.I., 1949, Progress report on the ground-water resources of the Louisville area, Kentucky.

Ryder, P.D., 1975, Ground water in the alluvium along the Levisa Fork of the Big Sandy River between Louisa and Pikeville, Kentucky.

Ryder, P.D., 1975, Ground water in the alluvium along the Licking River between Covington and Butler, Kentucky.

Shearman, J.O., and Swisshelm, R.V., Jr., 1973, Derivation of homogenous streamflow records in the upper Kentucky River basin, southeastem Kentucky.

Sublett, H.E., 1945, Chemical quality of ground water in the Louisville area, Kentucky.

Swisshelm, R.V., Jr., 1974, Low-flow characteristics of Kentucky streams.

Walker, W.H., 1957, An aquifer test in the southwestern part of the Louisville area, Kentucky.

Water-resources investigations of the U.S. Geological Survey in Kentucky, 1982.

\section{WATER-RESOURCES DATA REPORTS}

Surface-water records of Kentucky: 1961 through 1964 (one volume each year).

Water-quality records in Kentucky and Tennessee: 1964.

Water resources data for Kentucky, pt. 1, surface-water records, pt. 2, water-quality records: 1965 through 1980 (one volume for each year).

Water resources data for Kentucky--water year 1971, pt. 1, surface-water records, 1972 (PB-289 625).

Water resources data for Kentucky--water year 1971, pt. 2, water-quality records, 1972 (PB-289 626).

Water resources data for Kentucky--water year 1972, pt. 1, surface-water records, 1973 (PB-289 627).

Water resources data for Kentucky--water year 1973, pt. 1, surface-water records, 1972 (PB-289 628).

Water resources data for Kentucky--water years 1972-73, pt. 2, water-quality records, 1973 (PB-289 629).

Water resources data for Kentucky--water year 1974, pt. 1, surface-water records, 1975 (PB-289 630).

Water resources data for Kentucky--water year 1974, pt. 2, water-quality records, 1975 (PB-289 631).

Water resources data for Kentucky--water year 1975 (PB-251 853).

Water resources data for Kentucky--water year 1976 (PB-272 963). 


\section{WATER-RESOURCES DATA REPORTS--continued}

Water resources data for Kentucky--water year 1977 (PB-281 738).

Water resources data for Kentucky--water year 1978 (PB-296 401).

Water resources data for Kentucky--water year 1979 (PB-82-145 053).

Water resources data for Kentucky--water year 1980 (PB-81-223 612).

Water resources data for Kentucky--water year 1981 (PB-84-162 361).

Water resources data for Kentucky--water year 1982 (PB-84-162 320).

Water resources data for Kentucky--water year 1983.

Water resources data for Kentucky--water year 1984 (PB-86-162 526).

Water resources data for Kentucky--water year 1985 (PB-87-152 674).

Water resources data for Kentucky--water year 1986 (PB-88-137 492).

Water resources data for Kentucky--water year 1987 (PB-88-249 321).

Water resources data for Kentucky--water years 1988-1992 (one volume for each year).

\section{HYDROLOGIC INVESTIGATIONS ATLASES}

5 Map of the Louisville area, Kentucky, showing contours on the bedrock surface, by L.M. MacCary, 1955.

8 Availability of ground water for domestic use in Jefferson County, Kentucky, by L.M. MacCary, 1956.

10 Summary of occurrence of ground-water in Kentucky, by G.E. Hendrickson, 1958.

13 Reconnaissance of ground-water resources of the Jackson Purchase region, Kentucky, by L.M. MacCary and T.W. Lambert, 1962.

15-30 Availability of ground water in *** Counties, Kentucky, 1960-62. 15, Boone, Campbell, Grant, Kenton, and Pendleton. 16, Bracken, Harrison, Mason, Nicholas, and Robertson. 17, Lewis and Rowan. 18, Bath, Fleming, and Montgomery. 19, Clark, Estill, Madison, and Powell. 20, Boyle, Garrard, Lincoln, and Mercer. 21, Marion, Nelson, and Washington. 22, Bullitt, Jefferson, and Oldham. 23, Carroll, Gallatin, Henry, Owen, and Trimble. 24, Anderson, Franklin, Shelby, Spencer, and Woodford. 25, Bourbon, Fayette, Jessamine, and Scott. 26, Butler and Ohio. 27, Daviess and Hancock. 28, Union and Henderson. 29, McLean and Muhlenberg. 30, Hopkins and Webster. 


\section{HYDROLOGIC INVESTIGATIONS ATLASES--continued}

32 to 38 Availability of ground water in *** Counties, Kentucky, 1962. 32, Allen, Barren, Edmonson, Green, Hart, Logan, Metcalfe, Monroe, Simpson, and Warren. 33, Breckinridge, Grayson, Hardin, Larue, and Meade. 34, Caldwell, Christian, Crittenden, Livingston, Lyon, Todd, and Trigg. 35, Adair, Casey, Clinton. Cumberland, Pulaski, Russell, Taylor, and Wayne. 36, Breathitt, Floyd, Harlan, Knott, Letcher, Martin, Magoffin, Perry, and Pike. 37, Boyd, Carter, Elliott, Greenup, Johnson, Lawrence, Lee, Menifee, Morgan, and Wolfe. 38, Bell, Clay, Jackson, Knox, Laurel, Leslie, McCreary, Owsley, Rockcastle, and Whitley.

72 to 75 Geology and hydrology of alluvial deposits between the *** areas, Ohio River valley, Kentucky, 1963-64. 72, Hawesville and Cloverport areas. 73, South Portsmouth and Manchester Islands. 74, Lewisport and Owensboro. 75, Cattlesburg and South Portsmouth.

92, 93 Availability of ground water in the *** quadrangle, Jackson Purchase region, Kentucky, 1964. 92, Farmington. 93, Dexter.

94 to 98 Geology and hydrology of alluvial deposits between the *** areas, Ohio River valley, Kentucky, 1964. 94, Manchester Islands and Silver Grove. 95, Wolf Creek and West Point. 96, Spottsville and Reed. 97, Ethridge and Twelvemile Island. 98, Newport and Warsaw.

110, 111 Geology and hydrology of alluvial deposits along the Ohio River in the *** area, Kentucky, 1964. 110, Stanley. 111, Southwestern Louisville and West Point.

112 to 118 Availability of ground water in the *** quadrangle, Jackson Purchase region, Kentucky, 1964-65. 112, Lynn Grove. 113, Kirksey. 114, Briensburg. 115, Hardin. 116, Oak Level. 117, Elva. 118, New Concord.

124, 125 Availability of ground water in the *** quadrangle, Jackson Purchase region, Kentucky, 1964. 124, Hazel. 125, Lynnville.

129, 130 Geology and hydrology of alluvial deposits between the *** areas, Ohio River valley, Kentucky, 1964. 129, Uniontown and Wickliffe. 130, Prospect and Southwestern Louisville.

155 to 186 Availability of ground water in the *** quadrangle, Jackson Purchase region, Kentucky, 1965-68. 155, Little Cypress-Calvert City. 156, Fairdealing. 157, Symsonia. 158, Hico. 159, Birmingham Point. 160, Rushing Creek. 161, Cuba. 162, Water Valley. 163, Hickory. 164, Mayfield. 165, Hamlin-Paris Landing. 166, Westplains. 167, Crutchfield. 168, Heath. 169, Fancy Farm. 170, Dublin. 171, Joppa-Metropolis. 172, Lovelaceville. 173, LaCenter. 174, Melber. 175, Clinton. 176, Olmsted-Bandana. 177, Paducah West-Paducah East. 178, New Madrid SE--Hubbard Lake--Bondurant. 179, Milburn. 180, Cayce. 181, Hickman. 182, Oakton-Wolf Island. 183, Arlington-WickliffeWickliffe NW. 186, Cairo-Barlow. 


\section{HYDROLOGIC INVESTIGATIONS ATLASES--continued}

198

221

328

329

342

695

706

$$
\text { Water resources of the Appalachian Region, Pennsylvania to Alabama, } 1965 .
$$

Map showing altitude of the base of fresh water in coastal plain aquifers of the Mississippi Embayment, 1966.

Floods on Levisa Fork in vicinity of Paintsville, Kentucky, 1969.

Floods on Licking River in vicinity of Salyersville, Kentucky, 1969.

Floods on Triplett Creek in vicinity of Morehead, Kentucky, 1969.

Geohydrologic framework of the Gulf Coastal Plain, 1988.

Dissolved-solids concentrations and primary water types, Gulf Coast aquifer system, south-central United States, 1988.

\section{MISCELLANEOUS FIELD INVESTIGATIONS FIELD STUDY MAPS}

MF-865-D Map showing availability of ground water in Kentucky River Area Development District, Kentucky, by R.W. Davis, 1978.

MF-865-E Map showing quality of ground water in Kentucky River Area Development District, Kentucky, by R.W. Davis, 1978.

MF-865-F Map showing sulfate in selected streams in Kentucky River Area Development District, by R.W. Davis, 1978.

MF-865-G Map showing dissolved-solids concentration and $\mathrm{pH}$ of water in selected streams in Kentucky River Area Development District Kentucky, by R.W. Davis, 1978.

MF-865-H Map showing low flows, average flows, and drainage areas in Kentucky River Area Development District, by R.W. Davis, 1978.

\section{PUBLICATIONS OF THE KENTUCKY GEOLOGICAL SURVEY PREPARED BY U.S. GEOLOGICAL SURVEY RESEARCHERS}

These reports are available for inspection at the District Office, Louisville; at the Kentucky Geological Survey, University of Kentucky, Lexington; or the USGS Library in Reston, Virginia.

Bell, E.A., 1962, The ground-water situation in the Louisville area, Kentucky: Series 10 , Information Circular 10.

Davis, R.W., and others, 1974, Hydrology and geology of deep sandstone aquifers of Pennsylvanian age in parts of the Western Coal Field Region, Kentucky: Series 10, Report of Investigations 15.

Davis, R.W., and others, 1969, Water in the economy of the Jackson Purchase region, Kentucky: Series 10, Special Publication 20.

Hopkins, H.T., 1963, The effect of oilfield brines on the potable ground water in the upper Big Pitman Creek basin, Kentucky: Series 10, Report of Investigations 4. 


\section{PUBLICATIONS OF THE KENTUCKY GEOLOGICAL SURVEY PREPARED BY U.S. GEOLOGICAL SURVEY RESEARCHERS--continued}

Hopkins, H.T., 1966, Fresh-saline water interface map of Kentucky: Series 10.

Kirkpatrick, G.A., and others, 1963, Water resources of eastern Kentucky--Progress Report: Series 10, Report of Investigations 5.

Krieger, R.A., and Hendrickson, G.E., 1960, Effects of Greensburg oilfield brines on the streams. wells, and springs of the upper Green River basin, Kentucky: Series 10, Report of Investigations 2 .

Krieger, R.A., and others, 1969, Water in Kentucky: Series 10, Special Publication 16.

Kulp, W.K., and Hopkins, H.T., 1960, Public and industrial water supplies of Kentucky: Series 10 Information Circular 4.

Lambert, T.W., 1976, Water in a limestone terrane in the Bowling Green Area, Warren County, Kentucky: Series 10, Report of Investigations 17.

McCabe, J.A., 1962, Floods in Kentucky--magnitude and frequency: Series 10, Information Circular 9.

Morgan, J.H., 1967, Pumping test on an Eocene aquifer near Mayfield, Kentucky: Series 10, Information Circular 15.

Mull, D.S., Cushman, R.V., and Lambert, T.W., 1971, Public and industrial water supplies of Kentucky, 1968-69: Series 10, Information Circular 20.

Mull, D.S., and Pickering, R.J., 1968, Water resources of the Middlesboro area, Kentucky: Series 10, Report of Investigations 9.

Van Couvering, J.A., 1962, Characteristics of large springs in Kentucky: Series 10, Information Circular 8.

Whitesides, D.V., and Ryder, P.D., 1969, Effects of pumping from the Ohio River Valley alluvium between Carrollton and Ghent, Kentucky: Series 10, Information Circular 18.

Whitesides, D.V., and Nichols, E.S., 1961, Water levels in observation wells in Jefferson County, Kentucky, 1935-60: Series 10, Information Circular 6.

Whitesides, D.V., and Nichols, E.S., 1961, Water levels in observation wells in Kentucky excluding Jefferson County, 1948-60: Series 10, Information Circular 7.

Whitesides, D.V., 1971, Yields and specific capacities of bedrock wells in Kentucky: Series 10, Information Circular 21.

Wilson, E.N., and Van Couvering, J.A., 1965, A deep fresh-water aquifer in the New Cypress pool, Muhlenberg County, Kentucky, corroborated by geophysical logs: Series 10, Information Circular 12. 


\section{OTHER PUBLICATIONS OF U.S. GEOLOGICAL SURVEY RESEARCHERS FOR KENTUCKY}

Address inquiries about the availability of these publications to the publishers; however, some reprints are available from the Kentucky District office in Louisville. Most publications are also available at large public and university libraries.

Collier, C.R., and Krieger, R.A., 1958, Quality of surface waters of Kentucky, 1953-55: Kentucky Department of Economic Development, Frankfort.

Cushman, R.V., 1968, Recent developments in investigations in the karst area of central Kentucky: Memoires, International Association of Hydrogeologists Congress of Istanbul, 1967, v. 8, p. 236247.

Emery, P.A., 1980, Water resources activities of the U.S. Geological Survey: [Abs.] Symposium on Water Resources Research in Kentucky: Proceedings, Lexington, Kentucky, June 2-3, 1980, p.1.

Evaldi, R.D., and others, 1989, Effect of oil production on surface water quality in the Kentucky River basin, Kentucky: [Abs.] Kentucky Water Resources Symposium: Proceedings, Lexington, Kentucky, November 30-December 1, 1989, p. 5.

Evaldi, R.D., and Garcia, R, 1991, Evaluation of water-quality conditions at South Fork Cumberland River near Stearns, Kentucky: [Abs.] Kentucky Water Resources Symposium: Proceedings, Lexington, Kentucky, March 14-15, 1991, p. 3.

Evaldi, R.D. and Garcia, R., 1991, Quality of South Fork Cumberland River near Stearns, Kentucky: Second International Conference on the Abatement of Acidic Drainage: Proceedings, Montreal, Canada, September 16-18, 1991, p. 417-434.

Flanary, E.A., and others, 1989, Point and non-point source influences on dissolved oxygen, bacteria, and nutrient concentrations in surface waters of the Kentucky River basin. Kentucky: [Abs.] Kentucky Water Resources Symposium: Proceedings, Lexington, Kentucky, November 30-December 1, 1989, p. 7.

Flanary, E.A., and Evaldi, R.D., 1991, Surface water-quality assessment of the Kentucky River basin, 1976-1986: Constituent loads, trends, and sources: [Abs.] Kentucky Water Resources Symposium: Proceedings, Lexington, Kentucky, March 14-15, 1991, p. 21.

Forbes, R.W., 1991, Alternative graphics output within the GIS Environment: [Abs.] Kentucky Water Resources Symposium: Proceedings, Lexington, Kentucky, March 14-15, 1991, p. 91.

Forbes, R.W., 1989, Network Analysis Using a Geographic Information System: [Abs.] Kentucky Water Resources Symposium: Proceedings, Lexington, Kentucky, November 30-December 1, 1989 , p. 59.

Griffin, M.S., 1991, The use of satellite telemetry for the collection of real time data: [Abs.]

Kentucky Water Resources Symposium: Proceedings, Lexington, Kentucky, March 14-15, 1991, p. 7.

Grubb, H.F., and Zehner, H.H., 1973, Aquifer diffusivity of the Ohio River alluvial aquifer by the flood-wave response method: Journal of Research, U.S. Geological Survey, September-October 1973 , v. 1 , no. 5, p. 597-601. 


\section{OTHER PUBLICATIONS OF U.S. GEOLOGICAL SURVEY RESEARCHERS FOR KENTUCKY--continued}

Grubb, H.F., 1970, Effects of a concentrated acid on water chemistry and water use in a Pleistocene outwash aquifer: Ground Water, September-October 1970, v. 8, no. 5.

Grubb, H.F., and Arthur, J.K., 1989, Overview of Gulf Coast Regional Aquifer-System Analysis: [Abs.] Kentucky Water Resources Symposium: Proceedings, Lexington, Kentucky, November 30-December 1, 1989, p. 11.

Grubb, H.F., and Ryder, P.D., 1973, Regression techniques for estimation of sulfate in streams draining an area affected by coal mining: Third annual Engineering and Science Conference, Proceedings, Louisville, Kentucky, March 5-6, 1973, p. 127-137.

Guyton, W.F., 1946, Artificial recharge of glacial sand and gravel with filtered river water at Louisville, Kentucky: Economic Geology, v. 41, no. 6, p. 644-658.

Guyton, W.F., and others, 1945, Conservation of ground water in the Louisville area: American Water Works Association, v. 37, no. 6, p. 543-560.

Guyton, W.F., 1945, Depleted wells at Louisville recharged with city water: Water Works Engineer, v. 98 , no. 1 , p. $18-20$.

Haliday, A.C., 1989, Hydrography and drainage basin data base using a geographic information system: [Abs.] Kentucky Water Resources Symposium: Proceedings, Lexington, Kentucky, November 30- December 1, 1989, p. 57.

Hamilton, D.K., 1948, Some solutional features of the limestone near Lexington, Kentucky: Economic Geology, v. 43, no. 1, p. 39-52.

Hendrickson, G.E., 1959, Mineral springs in Kentucky: The Kentucky Naturalist, v. 13, no. 2, p. 31-34.

Hendrickson, G.E., and Krieger, R.A., 1960, Relationship of chemical quality of water to stream discharge in Kentucky: Proceedings, 21st International Geological Congress, Copenhagen, 1960, part 1, p. 66-75.

Hitchcock, H.A., 1992, WaterGage II, An alternative for present water-stage instruments: Proceedings, WRD Pressure-Sensor Workshop, Denver, Colorado, July 28-31, 1992, (in press).

Hupp, C.R., and Carey, W.P., 1990, Dendrogeomorphic approach to estimating slope retreat, Maxey Flats, Kentucky: Geology, July 1990, v. 18, p. 658-661.

Kiesler, J.L., Jr., 1986, Relation between surface-water quality and the composition of coal in Pike County, Kentucky: 1986 Symposium on Surface Mining, Hydrology, Sedimentology, and Reclamation: Proceedings, University of Kentucky, Lexington, December 8-11, 1986, 19 p.

Krieger, R.A., 1961, Ground-water contamination in the Greensburg oil field: U.S. Public Health Service, Cincinnati, Ohio, Proceedings 1961 Symposium, Ground-water contamination, Technical Report W61-5, p. 91-97.

Lamar, W.L., Krieger, R.A., and Collier, C.R., 1955, Quality of surface waters of Kentucky, 1951-53: Kentucky Board of Agriculture and Industrial Development, Frankfort. 


\section{OTHER PUBLICATIONS OF U.S. GEOLOGICAL SURVEY RESEARCHERS FOR KENTUCKY--continued}

Lamar, W.L., and Laird, L.B., 1953, Chemical character of surface waters of Kentucky, 1949-51: Kentucky Board of Agriculture and Industrial Development, Frankfort.

Liebermann, T.D.. 1989, Development and use of a geographic information system for Kentucky: [Abs.] Kentucky Water Resources Symposium: Proceedings, Lexington, Kentucky, November 30-December 1, 1989, p. 51.

Lyverse, M.A., 1986, Effectiveness of a ground-surface polymer membrane covering as a method for limiting infiltration into burial trenches at Maxey Flats, Kentucky: Eighth Annual U.S. Department of Energy Low-Level Waste Management Forum: Proceedings. Denver, Colorado, September 23-25, 1986, p. 120-126.

Lyverse, M.A., 1986, Movement of tritiated leachate through fractured rock at a low-level radioactive waste disposal site near Morehead, Kentucky: Third Annual East Regional Ground Water Conference: Proceedings, Springfield, Massachusetts, July 28-30, 1986, p. 465-471.

Lyverse, M.A., Starn, J.J., and Unthank, M.D., 1991, Simulation of the ground-water flow system in the alluvial aquifer at Louisville, Kentucky: [Abs.] Kentucky Water Resources Symposium: Proceedings, Lexington, Kentucky, March 14-15, 1991, p. 17.

Martin, G.R., Smoot, J.L., and White, K.D., 1989, A comparison of surface-grab and crosssectionally integrated stream sampling techniques: [Abs.] Kentucky Water Resources Symposium: Proceedings, Lexington, Kentucky, November 30-December 1, 1989, p. 75.

Martin, G.R., Smoot, J.L., and White, K.D., 1992, A comparison of surface-grab and cross sectionally integrated stream-water-quality sampling methods: Journal of Water Environment Federation, vol. 64, no. 7, November-December 1992, p. 866.

Martin, G.R., and White, K.D., 1991, Surface water-quality assessment of the Kentucky River basin, 1976-1986: Influences, conditions, and relation to criteria: [Abs.] Kentucky Water Resources Symposium: Proceedings, Lexington, Kentucky, March 14-15, 1991, p. 19.

Mueller, D.S., 1993, Bridge-scour analysis using the Water-Surface Profile (WSPRO) model: American Society of Civil Engineers' National Conference on Hydraulic Engineering Proceedings, (in press).

Mueller, D.S., and Landers, M.N., 1993, Development of bridge-scour instrumentation for inspection and maintenance personnel: American Society of Civil Engineers' National Conference on Hydraulic Engineering Proceedings, (in press).

Mueller, D.S., and Miller, R.L., 1993, Evaluation of historical scour at selected stream crossings in Indiana: American Society of Civil Engineers' National Conference on Hydraulic Engineering Proceedings, (in press).

Mull, D.S., Liebermann, T.D., Smoot, J.L., and Woosley, L.H., Jr., 1988, Application of dye-tracing techniques for determining solute-transport characteristics of ground water in karst terranes, U.S. Environmental Protection Agency, EPA 904/6-88-001, 113 p. 


\section{OTHER PUBLICATIONS OF U.S. GEOLOGICAL SURVEY RESEARCHERS FOR KENTUCKY--continued}

Mull, D.S., and Smoot, J.L., 1986, Ground-water flow characteristics described by quantitative dye tracing in karst terrane in North-Central Kentucky: Third Caribbean Islands Water Resources Congress: Proceedings, San Juan, Puerto Rico, July 22-23, 1986, p. 65-67.

Mull, D.S., and others, 1989, Ground-water quality at selected sites in the Meade County area, Kentucky, 1987-88: [Abs.] Kentucky Water Resources Symposium: Proceedings, Lexington, Kentucky, November 30-December 1, 1989, p. 49.

Mull, D.S., 1968, The hydrology of the Lexington and Fayette County, Kentucky area: Lexington and Fayette County Planning Commission, p. 24.

Mull, D.S., and Lee, D., 1984, Water Use in Kentucky, 1980: Kentucky Natural Resources and Environmental Protection Cabinet Atlas, Report DEP 1011, 1 sheet.

Mull, D.S., and Smoot, J.L., 1986, Ground-water flow characteristics described by quantitative dye tracing in karst terrane in the Elizabethtown area, Kentucky: Environmental Problems in Karst Terranes and Their Solutions Conference: Proceedings, Bowling Green, Kentucky, October 28-30, 1986, p. 407-422.

Mull, D.S., 1989, Quality control implications for the use of activated charcoal for dye tracing studies: [Abs.] Kentucky Water Resources Symposium: Proceedings, Lexington, Kentucky, November 30-December 1, 1989, p. 89.

Pollock, D.W., and Zehner, H.H., 1981, A conceptual analysis of the ground-water flow system at the Maxey Flats radioactive waste burial site, Fleming County, Kentucky, in Modeling and LowLevel Waste Management: An Interagency Workshop: Oak Ridge National Laboratory Report ORO-821, compiled by Little, C.A., and Stratton, L.E., p. 197-213.

Porter, S.D., 1991, Distribution of major ions and trace metals in streambed sediments of the Kentucky River basin: [Abs.] Kentucky Water Resources Symposium: Proceedings, Lexington, Kentucky, March 14-15, 1991, p. 23.

Porter, S.D., 1992, Relation of metal concentrations in annual growth layers in shells of freshwater mussels to long-term water-quality trends in the Kentucky River: Bulletin of the North American Benthological Society, v. 9, no. 1, p. 115.

Pree, H.L., Jr., and Walker, W.H., 1952, Memorandum on the geology and ground-water resources of the Calvert City-Gilbertsville area, Marshall County, Kentucky: Agricultural and Industrial Development Board of Kentucky, Frankfort, 13 p.

Price, W.E., Jr., 1960, Relation of geologic source, depth of well, and topographic location to yield of wells in the Eastern Coal Field region, Kentucky: [Abs.] Geological Society of America Bulletin, v. 71 , no. 12 , pt. 2, p. 1947-48.

Rorabaugh, M.I., 1953, Analysis of ground-water lowering adjacent to open water: American Society of Civil Engineers Proceedings, v. 118.

Rorabaugh, M.I., 1953, Graphical and theoretical analysis of step-drawdown test of artesian wells: American Society of Civil Engineers Proceedings, v. 79, separate 362. 


\section{OTHER PUBLICATIONS OF U.S. GEOLOGICAL SURVEY RESEARCHERS FOR KENTUCKY--continued}

Rorabaugh, M.I., 1956, Prediction of ground-water levels on basis of rainfall and temperature correlation: American Geophysical Union Transactions, v. 37, no. 4, p. 436-441.

Rorabaugh, M.I., 1951, Stream-bed percolation in development of water supplies: International Union Geodesy and Geophysics, International Association of Scientific Hydrology, Brussels, Belgium, v. 2, p 165-174.

Ruhl, K.J., and Martin, G.R., 1991, Low-flow characteristics of Kentucky streams: [Abs.] Kentucky Water Resources Symposium: Proceedings, Lexington, Kentucky, March 14-15, 1991, p. 9.

Ruhl, K.J., 1989, Low-flow characteristics of Kentucky streams: [Abs.] Kentucky Water Resources Symposium: Proceedings, Lexington, Kentucky, November 30-December 1, 1989. p. 99.

Ruhl, K.J., and Pulliam, P.J., 1989, Urban stream water quality in Louisville and Jefferson County, Kentucky: [Abs.] Kentucky Water Resources Symposium: Proceedings, Lexington, Kentucky, November 30December 1, 1989, p. 9.

Schrader, F.F., 1945, Kentucky's resources--Chapter on water: Kentucky University Bureau School Service: Education, Bulletin 2, v. 18.

Schrader, F.F., 1956, Streamflow in Kentucky: Kentucky Department of Economic Development, Frankfort.

Sholar, C.J., 1984, Causative factors and variation of sediment yields in Kentucky: Symposium on Surface Mining, Hydrology, Sedimentology, and Reclamation: Proceedings, University of Kentucky, Lexington, Kentucky, December 2-7, 1984, p. 141-147.

Sholar, C.J., 1989, The National Water-Use Information Program--As implemented in Kentucky: [Abs.] Kentucky Water Resources Symposium: Proceedings, Lexington, Kentucky, November 30-December 1, 1989 , p. 115.

Sholar, C.J., 1988, Water-use in Kentucky, 1985, with emphasis on the Kentucky River basin: American Water Resources Association: Proceedings, Water-Use Data for Water Resources Management, August 1988 , p. $85-92$.

Smoot, J.L., Effect of flow conditions on stream reaeration coefficients: 1989 Specialty Conference on Environmental Engineering, American Society of Civil Engineers: Proceedings, Austin, Texas, July 10-12, 1989, p. 781-787.

Smoot, J.L., Effect of streamflow conditions on gas-transfer coefficients: 1987 National Conference on Hydraulic Engineering, American Society of Civil Engineers: Proceedings, Williamsburg, Virginia, August 3-7, 1987, p. 980-985.

Smoot, J.L., 1989, Effects of flow conditions on stream reaeration coefficients: [Abs.] Kentucky Water Resources Symposium: Proceedings, Lexington, Kentucky, November 30-December 1, 1989, p. 3.

Smoot, J.L., Mull, D.S., and Liebermann, T.D., Quantitative dye-tracing of karst ground-water flow: 1989 Specialty Conference on Environmental Engineering, American Society of Civil Engineers: Proceedings, Austin, Texas, July 10-12, 1989, p. 677-684.

Smoot, J.L., Mull, D.S., and Liebermann, T.D., 1989, Quantitative dye-tracing techniques for describing contaminant-transport characteristics of ground-water flow in karst terrane: [Abs.] Kentucky Water Resources Symposium: Proceedings, Lexington, Kentucky, November 30-December 1, 1989, p. 85. 


\section{OTHER PUBLICATIONS OF U.S. GEOLOGICAL SURVEY RESEARCHERS FOR KENTUCKY--continued}

Smoot, J.L., Mull, D.S., and Liebermann, T.D., 1987, Quantitative dye-tracing techniques for describing the solute-transport characteristics of ground-water flow in karst terrane: Second Multidisciplinary Conference on Sinkholes and the Environmental Impacts of Karst: Proceedings, Orlando, Florida. February 9-11, 1987, 7 p.

Taylor, C.J., 1989, Fractures, karst lineaments, and their relationship to ground-water occurrence in the Inner Bluegrass Karst Region of central Kentucky: [Abs.] Kentucky Water Resources Symposium: Proceedings. Lexington, Kentucky, November 30-December 1, 1989, p. 93.

Unthank, M.D., and others, 1991, Investigation of a gasoline-contaminated aquifer near Greear in Morgan County, Kentucky: [Abs.] Kentucky Water Resources Symposium: Proceedings, Lexington, Kentucky, March 14-15, 1991, p. 53.

Unthank, M.D., 1989, Use of digital elevation data for watershed analysis: [Abs.] Kentucky Water Resources Symposium: Proceedings, Lexington, Kentucky, November 30-December 1, 1989, p. 55.

Walker, E.H., 1956, Reservoir capacity of Mississippian limestone in the Hopkinsville quadrangle, Kentucky: Geological Society of America Bulletin, v. 67, no. 10, p. 1431-1439.

White, K.D., 1988, Biodegradation of methanol and tertiary butyl alcohol in subsurface systems: [Abs.] U.S. Geological Survey Toxic Substances Hydrology Program--Technical Meeting: Proceedings, Phoenix, Arizona, September 26-30, 1988, 2 p.

White, K.D., and Gundersen, D.T., 1989, Water-quality and atmospheric deposition chemistry in the lower Ohio River Basin: An assessment of current and historical conditions: [Abs.] Kentucky Water Resources Symposium: Lexington, Kentucky, November 30-December 1, 1989, p. 73.

Whitesides, D.V., 1970, Common errors in developing a ground-water aquifer: Ground Water, no. 4, v. 8. July-August 1970, 4 p.

Wilber, W.G., and others, 1989, Concepts and plans for a National Water-Quality Assessment Program: [Abs.] Kentucky Water Resources Symposium: Proceedings, Lexington, Kentucky, November 30December 1, 1989, p. 61.

Zehner, H.H., 1973, Seismic refraction investigations in parts of the Ohio River Valley in Kentucky: Ground Water, no. 2, v. 11, March-April 1973, 10 p. 